\title{
Plume heads, continental lithosphere, flood basalts and tomography
}

\author{
DON L, ANDERSON ${ }^{1}$, YU-SHEN ZHANG ${ }^{2}$ \& TOSHIRO TANIMOTO ${ }^{\prime}$ \\ ${ }^{1}$ Seismological Laboratory, California Institute of Technology, Pasadena, California \\ 91125, USA \\ ${ }^{2}$ Institute of Tectonics, University of California at Santa Cruz, Santa Cruz, California \\ 95064, USA
}

\begin{abstract}
High-resolution uppermantle tomographic models are interpreted in terms of plate tectonics, hotspots and plume theories. Ridges correlate with very low velocity areas to a depth of $100 \mathrm{~km}$, probably a result of passively induced upwelling and partial melting. Past positions of ridges also exhibit very low seismic velocities in the uppermantle. At depths greater than $100 \mathrm{~km}$, some low velocity anomalies (LVA) may record past positions of migrating ridges. Buoyant upwellings induced by spreading do not track the migration of surface ridges; they lag behind.

At depths greater than about $150 \mathrm{~km}$ many LVA (Atlantic and Indian oceans) are more closely related to hotspots, and past positions of ridges than to current ridge locations. In the upper $200 \mathrm{~km}$ of the mantle, back-are and continental extension areas are generally slower than hotspot mantle, possibly reflecting partially molten and/or hydrous mantle. The Pacific ocean ridges tend to be LVA, and probably hot, to about $400 \mathrm{~km}$ depth.

The surface locations of hotspots, ridges and continental basaltic magmatism seem to require a combination of hot uppermantle and suitable lithospheric conditions, presumably the existence of tensile stresses. The bigh-velocity regions of the upper $200 \mathrm{~km}$ of the mantle correlate with Archaean cratons. Below $300 \mathrm{~km}$ the regions of generally fast seismic velocity, and therefore cold mantle, correlate with regions probably underlain by ancient slabs, where the uppermantle may be cooled from below. A moving plate, overriding a hot region, and being put into tension, will behave as if it were being impacted from below by a giant plume head.

At sublithospheric depths there are very large LVA (VLVA) in the Pacific and Indian oceans and in the North and South Atlantics. The large continental and oceanic flood basalt provinces seem to have formed over these large, presumably hot, regions. These VLVA do not appear to be plume heads nor is there any obvious damage to the lithosphere under the present locations of flood and plateau basalt provinces. The uppermantle does not appear to be isothermal; the LVA are not restricted to hotspot locations.

We suggest that LVA are hotcells in the uppermantle which reflect, in part, the absence of subduction cooling. Plate tectonic induced rifting causes massive magmatism if the break occurs over hotcells, i.e. low-seismic velocity regions. Flood basalts (CFB) may result from the upwellings of already hot, even partially molten, mantle. In contrast to plume heads and plume tails, hotcells are robust features which are fixed relative to one another. They are most pronounced in parts of the mantle that bave not been cooled by subduction. There is a close relationship between CFB initiation sites, LVA and ridges and, we believe, hotcells.
\end{abstract}

The driving mechanism of plate tectonics is now generally attributed to boundary and plate forces such as slab pull and ridge push (Forsyth \& Uyeda 1975) with the asthenosphere being re-* sistive or lubricative rather than forcing. Ridges are viewed as passive reactions to plate forces rather than the tops of convection cells (Lachenbruch 1976), Ridges are regarded as mobile but, even if passive, they may induce upwelling from some great depth, particularly at fast spreading ridges such as the East Pacific Rise (EPR). The existence of deep low-seismic velocity regions, such as at the East African Rift (EAR), may indicate a component of active upwelling. Ridges can migrate freely but the upwellings they induce will lag behind (Houseman 1983). Subduction zones migrate at a much slower rate than ridges.

Although plate forces are important the mantle is not completely passive. Lateral temperature and pressure gradients may exert an important influence on plate motions (Officer \& Drake 1983). These forces are generally ignored and this introduces certain paradoxes such as the rapid motion of the Indian plate in spite of the paucity of suitably located 'slab pull' regions and the presence of dragging continents.

The plume hypothesis originally put forward 
by Morgan (1971) assigns a major role to deep mantle plumes. These plumes, as conceived by Morgan and his co-workers, account for most of the mass transport out of the mantle and more than $50 \%$ of the heat flow. In this theory, plumes driye the plate and are, essentially, the main source of buoyancy and mass flow in the mantle,

In contrast, more recent plume theories (Campbell et al. 1989; Richards et al, 1989; Sleep 1990) consider plumes to be a secondary mode of conyection. Hotspots have been shown to account for only about $6 \%$ of the terrestrial heat flow and to be a minor source of material (Davies 1990). These types of hotspots and plumes are clearly quite different than the robust plumes treated by Morgan (1971). White \& McKenzie (1989) also consider plumes to be part of the large scale convective pattern of the mantle even though they are less voluminous than those treated by Griffiths \& Camphell (1990). White \& McKenzie (1989) attribute continental flood basalts (CFB) to lithospheric extension over hot upwellings whilc others assign a more active role to plumes in uplifting and breaking the lithosphere (Richards et al. 1989).

The small scale and perceived fixity of hotspots motivated the hypothesis of deep, narrow plumes originating below the effects of moving plates. The anomalous geochemistry of hotspot magmas gave additional impetus for siting their source deep (Schilling 1973; Anderson 1975). It is generally assumed that chemically depleted midocean ridge basalts (MORB) come from the asthenosphere, or shallow sublithospheric mantle, even though enriched basalts erupt at most times and places where one expects the shallowest mantle to be sampled. The most depleted basalts are associated with long-lived and rapid spreading, not the initial stages of lithospheric disruption. This suggests that the tracoclement and isotopic characteristics of hotspot magmas are acquired at shallow-depth. The shallow mantle is easily contaminated or metasomatized by a variety of mechanisms, (subduction, trapped melts) and may also house basalt-depleted (i.e. infertile) buoyent, harzburgites (Anderson 1981, 1983a, b, 1987a).

Technically, the 'asthenosphere' is a weak layer in the uppermantle but it is now generally assumed by geochemists and petrologists to be the depleted reservoir. Furthermore, the perceived attributes of the 'depleted asthenosphere' have been transferred to the whole uppermantle. Thus, the words 'asthenosphere', 'upper mantle', 'convecting mantle' and 'depleted mantle' are all used interchangeably in the current geochemical literature. We use uppermantle' to highlight the fact that semantics may be behind some of the current controversies. 'Uppermantle' means the mantle above the 650 $\mathrm{km}$ discontinuity. It contains the asthenosphere, the mesospherc (transition region) and the oceanic and continental mantle lithospheres. If the 'uppermantle' is defined as depleted, homogeneous and the MORB-source then, of course, it cannot provide enriched magmas (OIB, CFB) or be the source of plumes.

Recent theories of giant plume heads, and remobilized continental lithosphere (CL) filling up the asthenosphere have considerably weakened the arguments for a depleted isothermal homogeneous asthenosphere. The distinctive geochemistry of hotspot basalts may be acquired in the shallow metasomatized mantle even of the heat source is deep and the bulk of the basalt comes from a deep, fertile reservoir (Anderson $1983 b, 1985$ ).

If the uppermantle is inhomogeneous in composition and temperature, then the deep mantle plume hypothesis may not be necessary, or even viable. In particular, if continental insulation (Anderson 1982a, b; Gurnis 1988), recycling, metasomatism and subdaction can account for observed geochemical and temperature variations, all available data could be explained by an uppermantle origin of hotspot geochemistry. Temperature variations of about $200^{\circ} \mathrm{C}$ exist in the shallow mantle and there are hot regions unrelated to hotspots (Lago et al. 1990). Relative fixity of hotspots is a problem for all plume theories. Swell heights, geoid and heat flow can be satisfied with lateral variations confined to the upper few hundred kilometres (Moriceau et al. 1991). There is as yet no evidence from seismology, or any other source, that plumes originate deeper than about $300 \mathrm{~km}$ or that the broad low-velocity regions in the uppermantle are connected by narrow tails extending deep into the lower mantle. The $l=2$ component of lower mantle tomography correlates well with the $l=2$ component of the hotspot distribution (Hager \& Richards 1989) but shorter wavelengths correlate better with uppermantle tomo. graphy (Kedar et al, 1992).

High-resolution 3D images of the seismic velocity variation in the uppermantle bave recently become available (Zhang \& Tanimoto 1991a, b, 1992). Some of the current issues of plate tectonics and hotspots can now be addressed with data of high resolution from the third dimensions. We discuss these recent high-resolution tomographic results. The new images have a lateral resolution of about $1000 \mathrm{~km}$ to depths of about 500 and $100-200 \mathrm{~km}$ depth resolution, depending on depth. Pteliminary interpretations of these results are given in recent short 
papers (Zhang \& Tanimoto 1992; Anderson et al. 1992).

\section{Mid-uppermantle (290 km) (Fig. 1)}

This part of the mantle is well below the plate and should give us an iden of the plan form of mantle convection, including the locations of hot upwellings and plume hends. The mantle does not appear to be isothermal, It is characterized by large domains of both slow and fast seismic velocity. There is a general tendency for the seismic velocities in the mantle above about $300 \mathrm{~km}$ to be fast under continents and slow under oceans but this does not tell us the thickness of the plates. Many non-cratonic areas have fast velocities and some cratons have relatively slow velocitics at depths below about $220 \mathrm{~km}$. This is consistent with the moving plate being thinner than about $200 \mathrm{~km}$, the approximate thickness of the thickest elastic plate as determined from flexural studies (Anderson 1990).

Note the extremely broad LVA in the Pacific and Indian oceans. Clearly, these residual (or exterior) occans differ from the newly opened Atlantic and Arctic oceans (interior oceans), The mantle beneath the Pacific plate is particularly slow from the fastest spreading part of the Bast Pacific Rise (EPR) toward the NW, generally in the spreading direction. The EPR itself is not located in a particularly central position in this large thermal anomaly. If hot mantle is a necessary condition for the location of ridges and hotspots, these could be almost anywhere in the North Pacific. At this depth $(290 \mathrm{~km})$ hotspots (black squares) appear to be randomly distributed in broad low-velocity regions. Hawail is downstream from the EPR and is remote from plate boundaries and other hotspots. The Pacific plate is, of course, shrinking and there may be material converging, in the deeper mantle, toward the central Pacific. Hotspots are not characterized by large circular or ovoid LVA.

The lowest velocity regions are beneath SW North America, the Southern Marianna Arc, New Zealand (NZ), SE Asia, Indo China, the northern Indian ocean and near the Gulf of Aden. The deep LVA near New Zealand, and the Afar are well known (Driewonski \& Anderson 1981; Nataf et al, 1984, 1986). Many of the above areas exhibit lithospheric tension or are regions of recent spreading. The island are regions may be affected by volatile-fluxing due to slab dehydration.

Regions of current subduction tend to have fast seismic velocities below the shallow mantle (Nataf et al, 1986; Zhang \& Tanimoto 1991a; Zhou \& Anderson 1989). The slow velocities under NZ-Tonga-Fiji and Mariannas extend throughout the uppermantle (Figs 1-3) and could be the result of recent are-rise collision or back-arc spreading. At the resolution considered, there is no evidence for cold mantle in these regions although, undoubtedly, cold slab extends to the deepest earthquakes, about 680 $\mathrm{km}$. Since other covergence regions give the expected fast velocity signal it appears that resolution is not the problem. The above anomalous regions also do not have the high geoid signals associated with some other subduction zones.

The results around NZ-Tonga-Fiji, indicating a broad region of presumably hot and low density mantle are particularly important since there is no depression of the $650 \mathrm{~km}$ discontinuity (Richards \& Wicks 1990). A chemical boundary will be eleyated by hot mantle which will also elevate phase boundaries with negative Clapeyron slopes (i.e. cold material transforms at greater depth). The top of the lower mantle has high temperatures in this region (Tanimoto 1990 a) which would uplift chemical and phase boundaries and heat the base of the uppermantle, partially offsetting the cold slab effect.

The tomographic results show that most of the uppermantle at convergence regions with backarc spreading has low seismic velocitics and, presumably, low density. The question is, does the geoid reflect the thin dense slab (Hager \& Richards 1989) or the broad buoyant surrounding area? The effects on depression and eleyation of boundaries will probably be opposite for these two extremes. Many hotspots also exhibit geoid highs and LVA to about $200 \mathrm{~km}$ depth.

There are many very low-velocity regions (VLVA) that are not near botspots. It is likely that a combination of hot mantle plus appropriate lithospheric and stress conditions are required for hotspot upwellings to occur. The absence of hotspots above the VIVA in the northern Indian ocean is likely due to lithospheric compression in this region. Although this region is in a geoid low, suggesting perhaps some deeper cause for the lack of hotspots, it is little different from the Mt Erebus region in Antarctica, which has low seismic velocities, a geoid low, lithospheric extension (Davey 1981) and a hotspot (or at least, active volcanism). Other non-hotspot regions in geoid lows with high inferred uppermantle temperatures are the Pacific off North America, NE South America and the adjacent ocean, and the SW Atlantic. We suggest that these areas also have thick lithosphere or lithosphere under compression. The NE Pacific is a geoid low with hotspots, suggesting that lithospheric extension occurs in this region. Note that there are LVA in the wakes of 
the Americas, India, Australia and Greenland. These regions have recently been vacated by thick continental lithosphere.

The Mid-Atlantic Ridge (MAR) has migrated west and apparently decoupled from sume of the Atlantic hotspots at about $70 \mathrm{Ma}$, stranding them on the African plate ( $\mathrm{O}^{\prime} \mathrm{C}$-nnor \& Duncan 1990). At $290 \mathrm{~km}$ depth and deeper the uppermantle LVA does not follow the northern MAR but is offset to the east, following the central Atlantic hotspots. Ridges can move more rapidly than their associated upwellings (Houseman 1983), so this eastern Atlantic LVA may represent a previous location of the MAR or the position of continental break-up. There is also a discontinuous LVZ extending NW from Bermuda to Iceland and Jan Mayan. This may be due to the continental edge effect, discussed by Vogt (1991). He pointed out that the Bermuda swell paralleled the coast, as does the LVA, which is inconsistent with the hotspot hypothesis. Note also the LVA paralleling the Central Indian Ridge to the west and the E-W LVA south of the southern ridges, i.e, the former positions of these ridges. Spreading induced upwelling can extend to great depth and can still feed ridges which have migrated away. These passive upwellings may also leak material to the overlying hotspot. Theoretically, columnar type upwellings (plumes) are most stable near ridges (Cserepes \& Christensen 1990).

Note the gross global asymmetry in Fig. 1 between the slow Pacific hemispherc and the fast Eurasian, North Polar region and North American hemisphere. There is a broad LVA in the south central Pacific. Anderson (1987b) suggested that high temperatures in this region were responsible for extensive igneous activity in the Cretaceous. The plateaus in the western Pacific formed during a period of global plate reorganization, continental break-up and rapid spreading from centres in the Central Pacific. These spreading centres have since migrated toward the east. Other massive basalt provinces originated over what are now LVA in the Indian ocean, the $\mathrm{N}$ Atlantic and the S Atlantic. The VLVA in the S Indian ocean, which contains the Kerguelen-Heard hotspot, may represent the source of Gondwana magmatism and uplift, prior to rifting between India and Antarctica (Kent 1991).

Eurasia has not moved far since its assembly as the northern part of the supercontinent of Pangaes and it is therefore still underlain by foundered oceanic lithosphere. The high seismic velocities found throughout the uppermantle under Eurasia suggest that the mantle here has been cooled by cold subducted oceanic siabs.
There is a remarkable absence of hotspots in this vast region.

\section{The Mesosphere $(430$ and $490 \mathrm{~km}$ depth Figs 2 \& 3)}

The mesasphere, or transition region, is the region of the mantle between the two major seismic discontinuities at 400 and $650 \mathrm{~km}$ depth. The mesosphere is part of the uppermantle and is usually lumped with the asthenosphere or shallow mantle by petrologists (the depleted mantle', the 'convecting mantle'). However, it is mineralogically and rheologically distinct and may be chemically distinct as well. It may, for example, be the depleted reservoir and not well mixed with the shallow mantle. Much of the basaltic fraction of the Earth may be in this layer (Anderson 1983a, 1987a). This may be where slabs accumulate (Anderson 1979b, 1981, 1982c; Anderson \& Bass 1986). There is little correlation of the seismic velocities (Fig. 2) with present surface tectonics but good correlation with post Pangacatic subduction (Anderson 1982b, 1989). In some respects the velocities in the mesosphere are the negative images of shallow velocities; regions beneath convergence zones, cratons, young oceans and old oceans all tend to change sign. In particular, mid-ocean ridges are generally underlain by fast velocities and, presumably, cold mantle; old oceans, with thick lithospheres, are often above hot mesosphere. Subduction zones generally mark sharp lateral boundaries between slow and fast mantle, e.g. sce Tonga-Fiji, Marianas, Peru, Cascadia and the Aleutians.

The slowest regions are under central Africa (surface hotspots around the edges but not in the centre), the N Indian ocean (to hotspots), W Australia (craton), New Zealand-Kermadec (island are), W Pacific (stable ocean, no hotspots), SW USA (tectonic) and parts of eastern USA and northern Canada (stable). The fast regions generally correlate with expected locations of subducted oceanic lithosphere overridden by continents since the break-up of Pangaea. This is consistent with slab confinement to the uppermantle.

The high-velocity anomaly (HVA) beneath NE Australia is probably due to the subduction of the North New Guinea plate associated with the joining of North and South New Guinea. The high velocities in $\mathrm{E}, \mathrm{SE}$ and S Asia may be the result of long continued subduction of the Pacific, Kula, and various other oceanic plates over the past $230 \mathrm{Ma}$. The high velocities under Eurasia may be due to subduction related to 
closures of oceans as microcontinents assembled to form northeru Pangaea (Russian and Siberian platforms, Kazakhstan block, Tarim craton, Sino-Kotean craton).

Fast velocities are also prominent in areas where subduction has been long-lived (Kamchatka through Japan, Borneo, northen Australia through the New Hebrides, the Alpine belt, the Andes, the Bering Sea, and central Asia north of India). A belt of high velocities paralleling the Cordillera and extending from the Canadian Arctic through central North America, the Caribbean and down west central South America probably represents older subduction, due to the overriding of Pacific ocean plates by the Americas. The locations of these fast bands are where the active margins of the Americas were some $\mathbf{4 0}$ to $\mathbf{7 0}$ million years ago, The fast belt extending across the Alps and into Saudi Arabia is possible Tethyan lithosphere (due to closure of an old ocean).

LVA in this depth interval again occur in the wakes of drifting continents. These are particularly evident for North America, India, and Antarctica but are also seen east of South America, south of Australia and east of Greenland. The former positions of migrating ridges also are cvident, particularly the central Atlantic ridge, which has moved west, and the Indian ocean ridges, which have moved east and north. The mid-Pacific at one time had ridges and triple junctions and, at that time, passive rifting caused upwellings and partial melting. Houseman (1983) showed that such upwellings will not follow the ridge if the ridge migrates too fast. Absence of subductive cooling and presence of heating from below are other mechanisms for generating bot Pacific uppermantle. There are LVA, and presumably hot upwellings, in the lower mantle under the central Pacific and Africa (Tanimoto 1990a). Even if there is no transfer of material there will certainly be transfer of heat from the lower to the uppermantle. Hot buoyant upwellings (and LVA) in the transition region (mesosphere) can be caused by heating from below, continental extension, ridge migration and intrinsic instability caused by partial melting of phase changes, Contrary to popular belief all upwellings do not have to originate in a thermal boundary layer.

We can speculate that the linear LVA, with three hotspots, NW of Africa may mark the mantle source for Jurassic pre-drift volcanism along the east coast of North America (Newark group, White Mountains, and eastern North America dyke swarms) and that the material from this region is now feeding the MAR and the Azores in preference to the overlying botspots which are on old, thick lithosphere. If the linear LVA, offset from the MAR, is a passive upwelling, then we might expect that the overlying hotspots will die out as the ridge migrates further west. The African plate is nearly stationary and it is no surprise that eastern Aflantic hotspots are nearly fixed. Note that the Kerguelen plateau is at one extremity of a VLVA in the southern Indian ocean.

\section{The outer shell (Fig. 4)}

Figure 4 shows the shear velocities at a depth of $66.1 \mathrm{~km}$ near the top of the mantle. Note the 'ring of fire' around the Pacific, and the slow velocities associated with ridges and back-arc basins (Zhang \& Tanimoto 1992). Old crust is generally underiain by fast mantle. Tectonically stable regions tend to be fast, a combination of low temperatures and a refractory mineralogy (Jordan, 1975, 1978; Anderson \& Bass 1984). Mantle temperatures were much hotter when ancient shield mantle formed, depleting it so effectively in low melting components, that cratonic mantle is well below the solidus. Although cold, it is probably buoyant because of $i$ ts chemistry (low $\mathrm{Fe}, \mathrm{Al}$ ) and mineralogy (low gatnet). Archaean komatiites apparently melted at temperatures well in excess of those inferred for hot present day mantle. If cratonic mantic lithosphere is the residue of such bigh-temperature melting then it will be immune to damage by present-day hotspot magmas.

Figure 5 shows velocities at $130 \mathrm{~km}$. The fastest regions, without exception, are associated with Archaean shields. The Indosinia block (Cambodia) and Arabia are the only shields that are not HVA. Evidence for the former is weak. Even the small Tarim shield in China shows up as a HVA. Note that most of the Atlantic and Indian ocean ridges follow the lowest velocity regions but are now offset in some regions compared with the shallower mantle zone in Fig. 4. This suggests when other depths are also considered, that most ridges are passive, with hot material upwelling into the space made available by plate spreading (Lachenbruch 1976). Melting occurs during adiabatic decompression and this, plus the high temperature, causes very low seismic velocities. This also induces, by continuity arguments, upward flow from greater depth, a form of convection triggered from above. Note that most of the Atlantic and Indian ocean hotspots are embedded in hot, slow mantle at this depth. These hotspots are related to present or past positions of the ridge. If the migration of ridges is taken into account, the close association of hotspots with ridges, present and recent, is 
quite remarkable. There are also many hotspots close to continental edges. Discontinuities in lithospheric thickness can also set up small scale convection (Vogt 1991).

The Pacific ridge systems are embedded in very broad low velocity areas (LVA), with the Nazea and Cocos plates being entirely underlain by slow mantle which forms an asymmetric LVA around the EPR. Parts of the Australian-Antarctic and SW Indian ridges are not LVA at this depth, suggesting slow spreading or cold underlying mantle or very shallow meiting. Note the discontinuity near the Australian-Antarctic Discordance (AAD). This is a deep ridge, low geoid region and the boundary between geochemical domains (Klein et al. 1988). It appears that the eastern part of the ridge south of Australia is being fed from the Pacific side. These types of ridges may be completely passive, existing only because of geometric constraints.

Many hotspots are located in very large lowvelocity anomalies (Iceland, Hawail, Azores) but again the sizes, shapes and trends of these VLVA, at present resolution, are not related to plate motions. There are other similar VLVA and LVA which are not obviously related to surface hotspots. As postulated earlier, these may also provide massive outpourings of basalt, such as CFB or oceanic plateau basalts (OPB), if plate reorganization puts the overlying lithosphere into extension. Hotspots may be the focused effect of upwelling triggered from above by extensional strains or discontinuities in the lithosphere. The extent of the volcanism would depend on the temperature and history of both the lithosphere and asthenosphere. There may also be instabilitics at the top of a partially molten layer. These can also be triggered from above. Spreading centres can migrate away from upwellings they induced, upwellings which may still be manifest as volcanism on the overlying plate as well as by lateral transport to the ridge. The maximum depth extent of VLVA is unknown. This will only be evident when highresolution methods are developed for greater depths. At the moment all we know is that the large scale patterns of velocity anomalies are not everywhere continuous across the $650 \mathrm{~km}$ discontinuity (Tunimoto 1990b).

The backarc basins in the western Pacific, and sites of subduction or recent subduction, are among the slowest regions at shallow depths. The slowest regions include W North America, New Zealand, SE Asia, the Philippine Sea plate, E Pacific and NE Australia-Coral Sea. Low seismic velocities can be explained by high temperatures and partial melting. The latter sets in at lower temperatures for volatile-rich mantle.
The extremely low shallow mantle velocities in convergent regions, particularly those with active backarc spreading, may be due to the high volatile content caused by dehydration of subducted oceanic crust and volatile-fluxed melting of the mantle wedge. The volatile fuxed or metasomatized material may constitute an important part of the shallow mantle, even away from subduction zones and continental lithosphere (Anderson 1982c). The volatiles released by subducting slabs are not entirely accounted for by island arc volcanism and may be stored in the shallow mantle. The buoyant material may explain why ridges, surface hotspots and trenches are mostly in geoid highs and have low seismic velocities in the shallow mantle. The dense slab will also contribute to the geoid but note that many ridges and hotspots also have underlying fast (cold) regions in the mesosphere.

Note that the ridges are not underlain uniformly by slow material in the uppermantle. There are particulariy slow regions in the north and south Atlantics, around triple junctions and near some hotspots. Ridges are also not uniform in depth or chemistry. Regions of continental extension (e.g. Rhinegraben, Kenya Rift, SW USA) have slow seismic velocities. Note the low velocities associated with lithospheric extension near Lake Baikal and the East African Rift, The LVA associated with the latter extends to great depth but the Lake Baikal region is underlain by cold mantle and will probably never be an active magmatic centre.

Note that the older parts of the Atlantic and Pacific oceans are fast, indicating, in part, thickening of the lithosphere. Some of the material represented in this depth slice is entrained, sublithospheric material and thermal boundary layer (TBL). In contrast to White (1988) we do not equate the lithosphere with the TBL, which can be twice the thickness of the strong layer. The lower half of the TBL constitutes part of the perisphere (see below).

In most models of plate tectonics and hotspots, bathymetry is due to lithospheric thickening over a homogeneous, isothermal mantle with perhaps a few interruptions by hotspot swells which are thought to represent the tops of deep mantle plumes. There is supposed to be no deep contribution to oceanic bathymetry (e.g. White 1988). The tomography, and recent geoid studies, indicate that this is much too simple a view. Ridges and hotspots are embedded in larger scale warm uppermantle provinces. Hotspots are not centrally located above the hottest mantle nor is hottest mantle always associated with hotspots. Recent geoid studies (Baudry \& Kroenke 1991; Maia \& Diament 


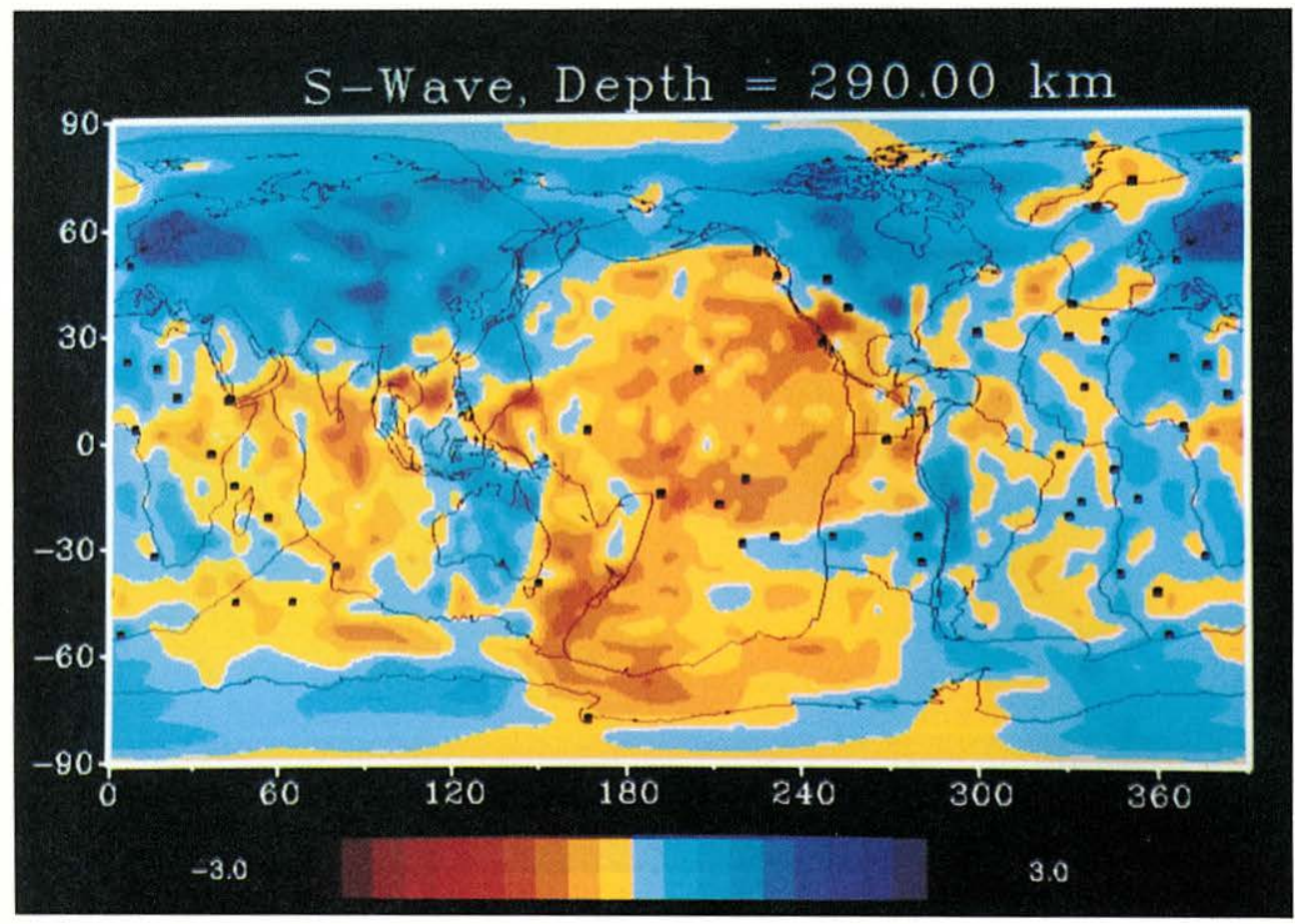

Fig. 1. Shear velocities at a depth of $290 \mathrm{~km}$ (after Zhang \& Tanimoto 1991a). Continental and plate boundaries are shown. The dots are hotspots. Blue regions have fast seismic velocities and are probably cold. Orange is slow and hot. Note that the total range of velocity variations changes (decreases) with depth.

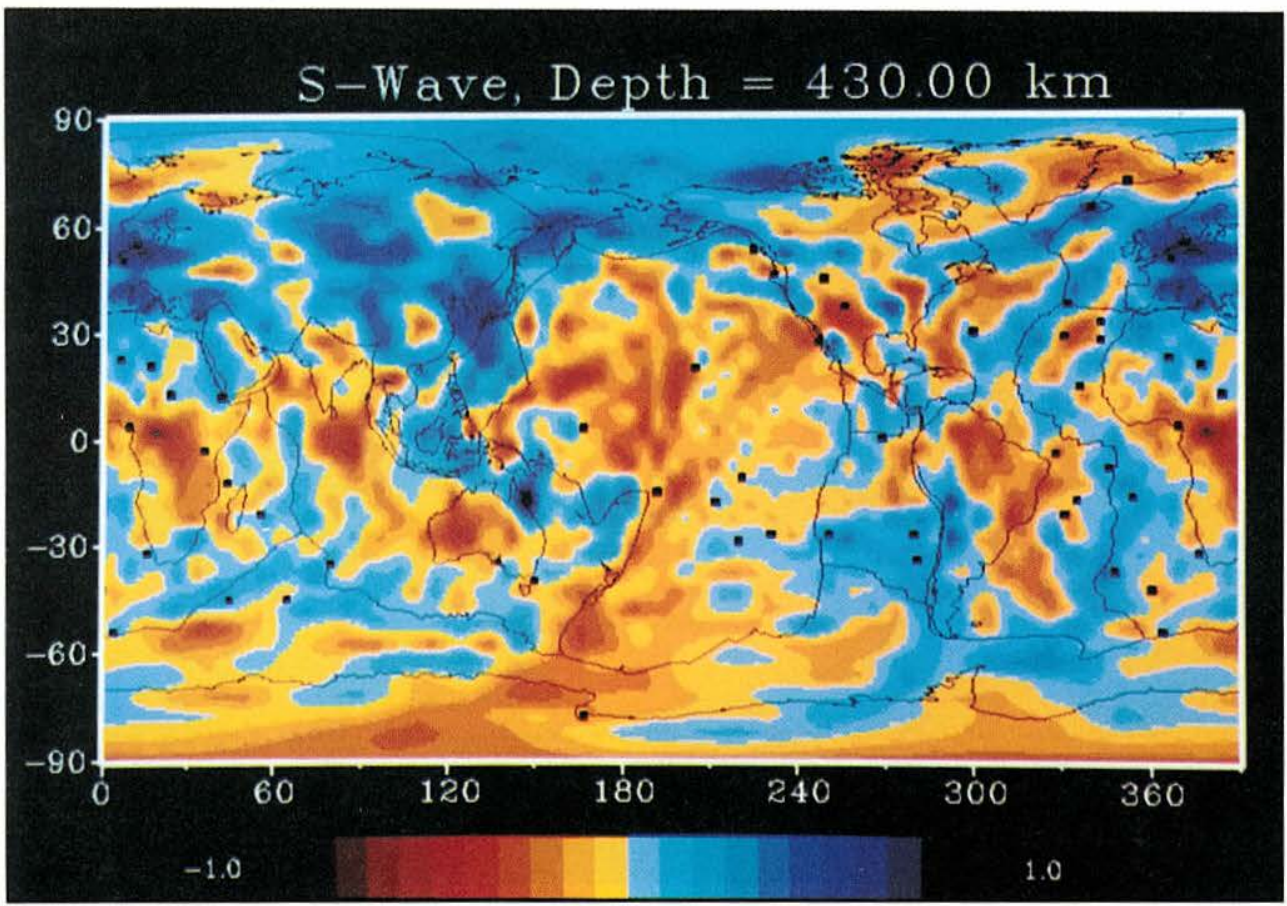

Fig. 2. Shear velocities at a depth of $430 \mathrm{~km}$. See Fig. 1 for details. Note the change of the scale of velocity variation. 


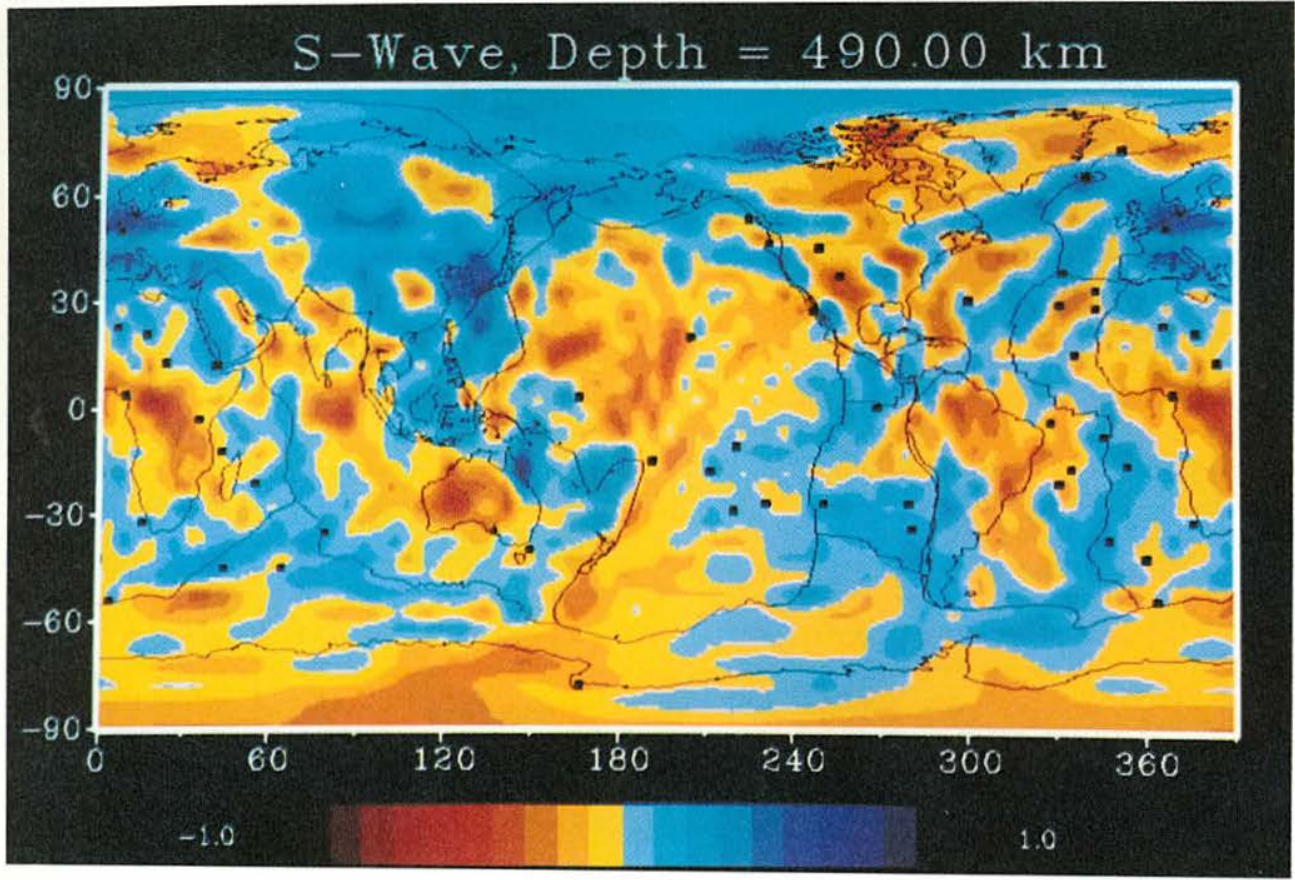

Fig. 3. Shear velocities at a depth of $490 \mathrm{~km}$. See Fig. 1 for details.

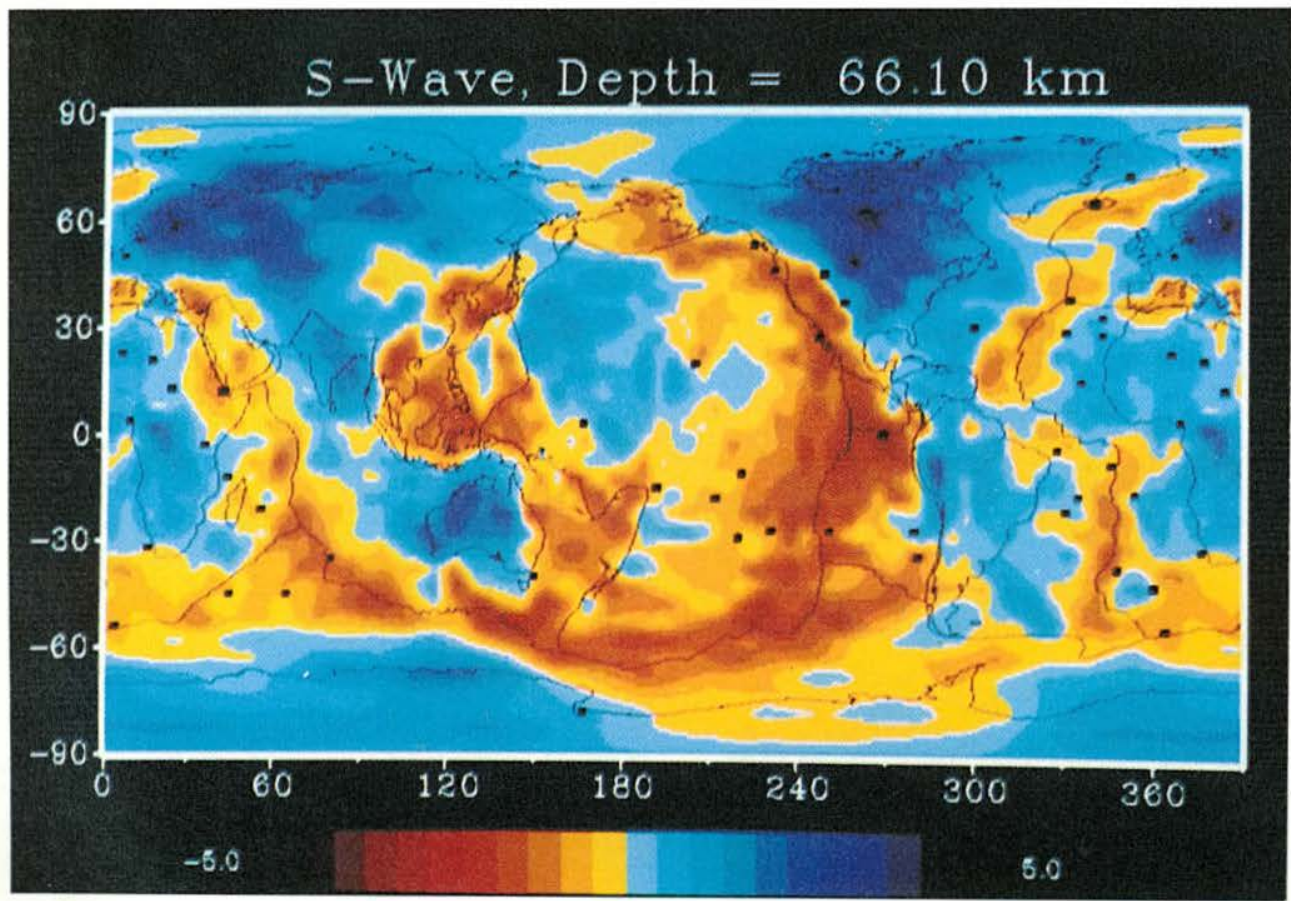

Fig. 4. Shear velocities at a depth of $66.1 \mathrm{~km}$. See Fig. 1 for details. 


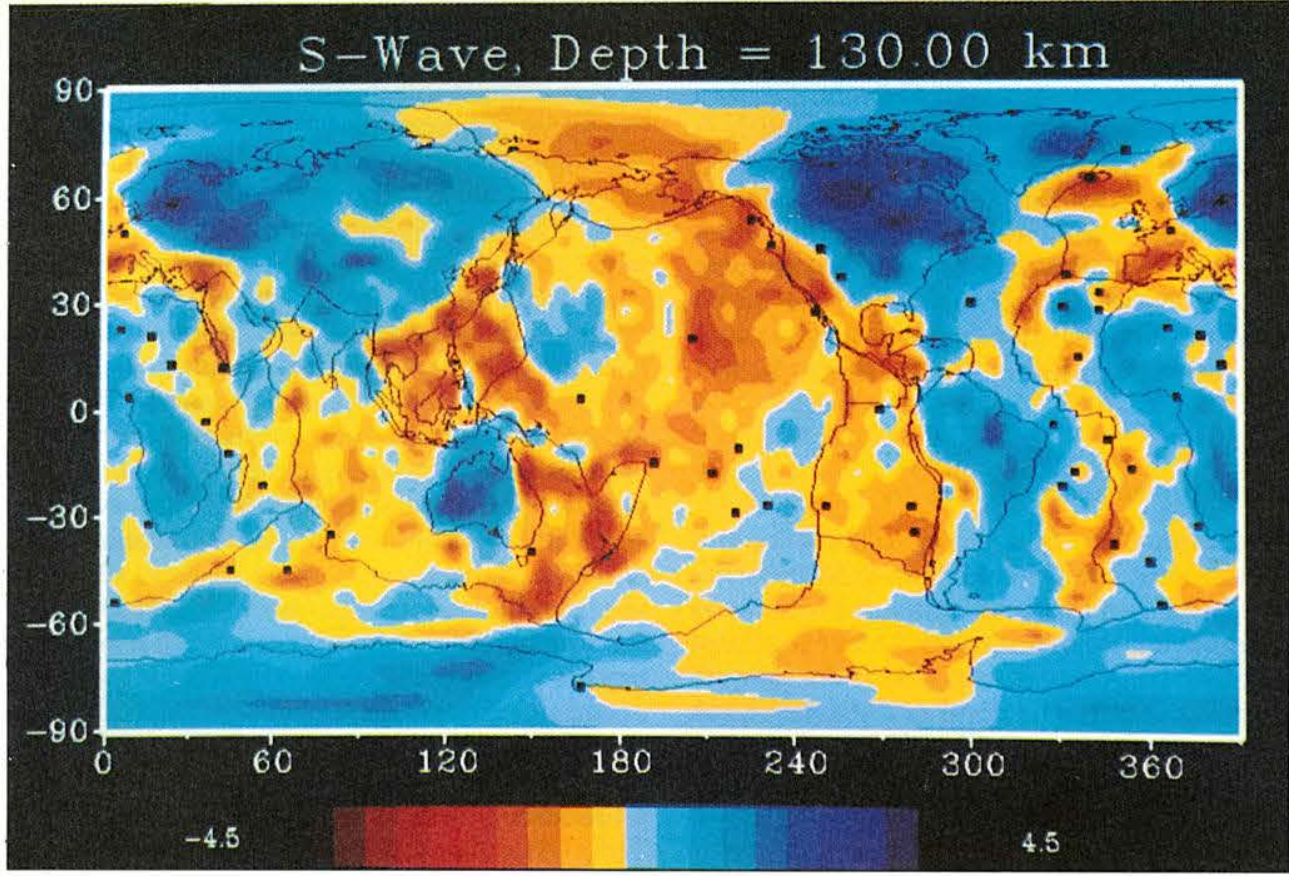

Fig. 5. Shear velocities at a depth of $130 \mathrm{~km}$. See Fig. 1 for details.

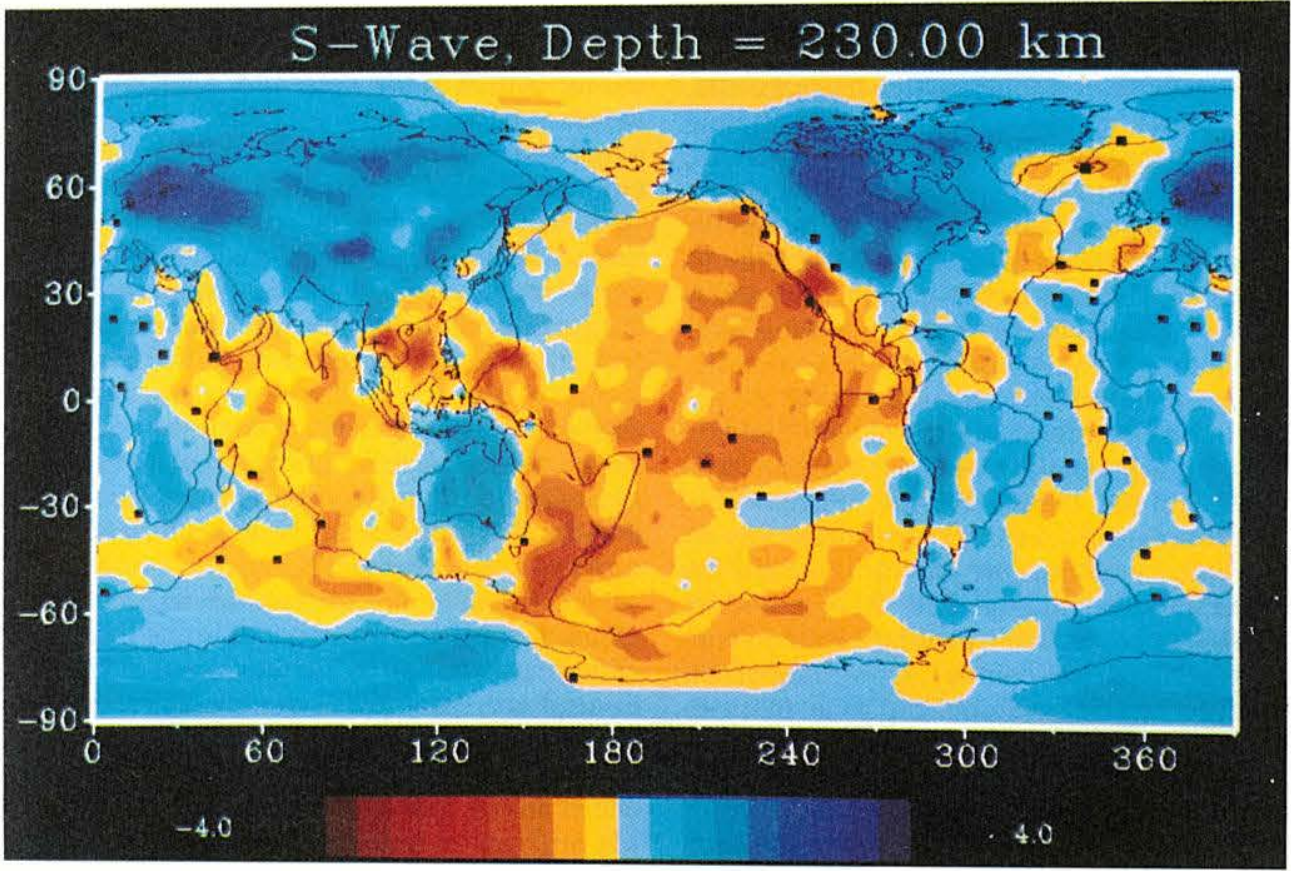

Fig. 6. Shear velocities at a depth of $230 \mathrm{~km}$. See Fig. 1 for details. 
1991) show that Pacific hotspots are embedded in long geoid highs but are not at one end. One gets the impression that it is a combination of hot mantle and suitable lithospheric conditions that determines where hotspots emergc. CFB provinces are also generally on the edges of Archacan cratons and, when corrected for continental drift, originated over regions that are now LVA. Adiabatic ascent from $c, 150 \mathrm{~km}$ under rifted cratons may result in more extensive melting than upwellings under thinner lithosphere.

\section{Asthenosphere (230 km Fig. 6)}

The close association of the E Atlantic sinuous LVA with past positions of the westwardly migrating MAR, and with hotspots, is particularly well displayed by this image. At even greater depth, this LVA breaks up and loses its continuity (Fig. 1). The Iceland and Azores LVA are not centred, or most prominent, under the surface expression of the hotspots but the islands are near the ridge, the most convenient access of material from the LVA from depth to the surface.

\section{Discussion}

If long linear LVA are passive upwellings associated with spreading ridges, then the association of deep LVA with hotspots must be explained. Hotspots, in most current theories, are active upwellings, possibly from the lower mantle, which control the locations of continental break-up (Morgan 1983). On the other hand, continents tend to break-up along pre-existing lines of weakness, generally following suture zones and mobile beits and avoiding cratons until the final separation. Hotspots and ridges may also be induced by plate spreading over a non-Lomogeneous, non-isothermal mantle, with the geometric and chemical characteristics controlled by conditions in the shallow mantle and asthenosphere as well as by the fluid dynamics of the deeper mantle. Plate forces (slab pull, plate thickening) may uitimately be responsible for rifting (the passive case) but the actual lecation and timing of the rift or midocean ridge may be controlled by sublithospheric conditions (perhaps, hot mantle). Upwelling of this hot mantlc may be facilitated and made more intense by the spreading suction. Thus, the distinction between active and passive spreading and upwellings is not necessarily very clear.

Plate motions have a large effect on convective motions in the mantle. Plume-like upwellings oecur only near diverging plates; midplate plumes are not steady features (Cserepes \& Christensen 1990). The plume-like structures near ridges cxtend throughout the system while the sheet-like upwellings are shallow features. An important question is, how long can a plumelike upwelling oxist after a ridge has migrated away; can Hawail be the result of a c. $100 \mathrm{Ma}$ triple junction that has since migrated away?

According to recent ideas (Campbell \& Griffiths 1990; Griffiths 1986) continental flood basalts (CFB) represent plume heads associated with the initiation of deep mantle plumes. Others suggest that the continental lithosphere is 'remobilized', 'delaminated', 'pre-weakened' or otherwise damaged or removed in the processes of flood-basalt magmatism (Hawkesworth ef al. 1986; Mahoney et al. 1989). If these scenarios are true, there should be low seismic velocities in the upper $100-200 \mathrm{~km}$ of the mantle under continents where continental flood basalt provinces occur. Places to look for this effect include the North Atlantic Tertiary Province (NATP; Greenland, Scotland, Norway), the ParanáEtendcka (Brazil, SW Africa), the Deccan (W India), the Karoo (SE Africa) and the Siberian Traps. None of these areas show any evidence for entrained plume heads or removed lithosphere, Conductive cooling extends to about 200 $\mathrm{km}$ in about 200 million years, so there is little chance for conductive cooling of a hot plume head emplaced at about $200 \mathrm{~km}$. Continental flood basalts may rather be associated with lithospheric extension associated with a continent moving over hot areas (LVA) of the mantle which may, in fact, be partially molten prior to extension. Note the VLVA in the North Atlantic (source of NATP, 7Siberia), W. Indian ocean (Deccan) and S Indian ocean (Karoo) where these CFB are presumed to have formed. These are all regions which have not experienced postPangaeatic subductive cooling. The hot mantie inferred to exist under hotspots and CFB may not have experienced cooling by subduction. Note that inferred backtracked locations of massive Cretaceous volcanism (Pacific plateaus, Kerguelen) and other flood basalts are VLVA (SE Pacific, S Indian ocean, N Atlantic, etc.). Hot areas of the uppermantle may be due to the absence of cooling rather than the importation of plume heads from great depth in the mantle. In addition fo cooling by subduction of old oceanic lithosphere, instabilities in old continental TBL can also deliver cold material to the uppermantle. Most of the Pacific ocean bas not experienced any of these kinds of cooling for 200-500 $\mathrm{Ma}$ and can be expected to contain hotter than average convection cells. Intense magmatism in the Pacific may be related to plate reorganiza. 
tion over hot mantle and unrelated to giant plumes or plume heads.

There are large lateral variations in seismic velocity at all depths in the uppermantle. These are most pronounced in the upper $300 \mathrm{~km}$ wherc a given change in temperature bas the greutest effect because of phase changes and partial meiting (Anderson 1989). Dehydration reactions in downgoing slabs also contribute to shallow seismic velocity variations. The smaller variations at greater depth cannot be used to argue that most of the uppermantle is isothermal. The relatively small velocity variations below $400 \mathrm{~km}$ are significant and do not imply smaller temperature variations than at shallow depths. Relatively small density variations at this greater depth are implied.

The Pacific and Indian oceans are clearly distinct from the Atlantic ocean. This may be related to the location of Pangaea, previous ocean closures, and post-Pangacatic subduction. Hotspots are generally embedded in broad low velocity regions of the uppermantle but lithospheric conditions and present and past locations of plate boundaries may also influence the positions of low velocities and hotspots. Previous positions of the mid-Atlantic ridges and SE Indian ocean show up as 'ghost' low-velocity zones in the uppermantle.

Some of the older parts of the Attantic, Pacific and Indian oceans have slower than average velocities below some $300 \mathrm{~km}$ depth. These appear to be generally unrelated to hotspots or to deep mantle effects. Although their source is unknown, these are undoubtedly buoyant regions which should contribute to the bathymetry of old ocean basins. In fact, the departure of old oceanic lithosphere from the square-rool-time law is well known. It has been attributed to small scale convection, lithospheric delamination and dynamic support (Parsons \& Sclater 1977; Colin \& Fleitout 1990; Cazenave \& Lago 1991). The tomography favours a sublithospheric explanation. The absence of surface hotspot expressions under most old oceanic lithosphere suggests strong lithospheric, perhaps under compression, rather than absence of hot mantle. Most hotspots on old oceanic lithospheric are near fracture zones or continental edges and, in fact, probably started under contineats (Wilson 1990). The large number of hotspots on the African plate may be related to its central position in the supercontinent of Pangaea, or to the fragmentation of Pangaea.

\section{Lithospheric extension v, deep plumes}

It is likely that the Rhinegraben and Lake Baika! are in regions of externally induced tension, pos- sibly due to collision of Africa and India, respectively, with Eurasia, and that their volcanism is entirely passive rather than related to hotspots or sublithospheric LVA. They have low seismic velocities between 100 and $200 \mathrm{~km}$. However, below $300 \mathrm{~km}$ both regions appear to be very cold. The Eiffel 'hotspot' does not have the time progressive track originally attributed to it (Cantarel \& Lippolt 1977) and may not be a deep seated thermal anomaly. The rift related quaternary volcanism in B China lies above deep, cold regions which surrounds a deep hot region. The East African Rift (EAR), the Gulf of California, the Gulf of Aden and the Rio Grande Rift are above deep LVA.

The surface expression of hotspots is associated with shallow LVA, spreading centres (past and present), continental edges, and absence of slabs. However, the relation between hotspots and LVA changes with depth. The above observations are all consistent with lithospheric control on the surface locations of some, if not most, hotspots and a general control by post-Pangreatic subduction on high velocities in the transition region (and the absence of hotspots). Old slab probably underlies most of Austratia, the Americas and S and E Asia. These areas have few hotspots. Even older slab probably underlies much of N Asia, another hotspot iree area.

Many proposed hotspots are underlain by colder than average mantle below $200-400 \mathrm{~km}$ depth (e.g. St Helena, Tristan da Cunha, Iceland, Easter, Nunivak, San Felix, Juan Fernandez, Hoggar, Tibesti, E. China, Eiffel, Azores, Ascension, Galapagos, Crozet and Amsterdam). Almost all of these hotspots are near fracture zones, rift zones and lithospheric discontinuities, or the effects discussed earlier, and some have becn questioned as hotspots based on other considerations. Some of these may be plate boundary and triple junction phenomena and some may be due to plate reorganization.

Many hotspots are actually hot lines, or erupt for long periods of time after leaving the point of initiation, or do not exhibit the predicted age progression, or are up to $1000 \mathrm{~km}$ away from the conjectured plume (Veevers 1984; Okal \& Batza 1987; Phipps 1988; O'Connor \& Duncan 1990). If hot mantle actually has the dimensions and shapes of the scismic LVA then these observations, combined with lithospheric control of exit points, can be understood. The similarity in isotope and trace-element chemistry between continental and oceanic magmas along some hotspot tracks argues for an extended sublithospheric source rather than a CL or plume head source.

These kinds of observations are often attrib- 
uted to shallow channels or tilted plume conduits or attachment of the plume head to the moving lithosphere. Alternatively, there may be a global enriched (metasomatized) sub-lithospberic layer, which could explain the catholic nature of enriched basalts, and hotter than average convection celis in the uppermantle. The uppermantle has multiple convection cells and these are unlikely to all have the same temperature, particularly considering their different histories.

The hotspots which are embedded in broad and deep LVA include Samoa, Mt Erebus and East African Rift volcanoes. These seem to be regions where the lithosphere is breaking duc to plate tectonic boundary forces, over extended regions of particularly hot mantie. These surface hotspots may be fed by a large high-temperature uppermantle region, or hot convection cells, rather than by a narrow, deep, feeder tube, as in the plume theories, Other hotspots over extens. ive and deep LVA (hotcells?) include Hawaii, Réunion, Canaries, Cape Verde, Kerguelen and Tasmania. These are all, currently, non-ridge hotspots. Few of the on-ridge or near-ridge hotspots occur ovet slow (hot) mantle that extends as deep as 300 or $400 \mathrm{~km}$. Most ridges, however, are migrating. Hawaii occurs near the boundary of hot and cold, or less hot, uppermantic and is related to an extensive NS trending LVA. Other regions, such as eastern China, which are generally not considered hotspots, in spite of the hotspot chemistry of the magmas, are associated with deep LVA, which, however, are often offset from the surface volcanism. The concepts of large lateral iransport distances, and large regions of high temperature (VLVA, LVA), feeding localized surface volcanoes, are at variance with the concept of narrow (100$200 \mathrm{~km}$ ) plumes which are absolutely fixed with respect to one another. However, common amendments to piume theories involve large plume heads, easy capture of plumes by ridges, long distance lateral plume flow through shallow channels, large geochemical radius of influence around plumes and tilting of plume conduits by mantle flow. These modifications to the 'hotspot' models are unnecessary if the mantle is not isothermal, and if the uppermantle is not homogeneous, i.e. there may be a global metasomatized shallow layer which provides the geochemical signature often attributed to deep mantle sources.

Although it is generally assumed that the Parana basalts formed over a fixed Tristan hotspot there are difficulties with this interpretation (Morgan 1983). Plate reconstructions apparently require motion of this hotspot (Molnar \&
Stock 1987; Peate et al. 1990), It appears that the mantle source for the Parana is displaced from the predicted position of Tristan and that it is laterally extensive. We suggest that the Paraná CFB formed over one of the South Atlantic LVA south of Tristan de Cunha. These LVA may represent hotcells.

We also suggest that the Gondwana flood basalt province extending ucross Africa, Antatetica, India, Australia (Karoo, Ferrar, Tasman) formed when this region was above the LVA ( 66 to $>290 \mathrm{~km} \mathrm{depth)}$ in the southern Indian ocean, perhaps centrcd on Kerguelen. This region has apparently had anomalously high temperatures since at least $270 \mathrm{Ma}$ (Kent 1991). However, we see no reason for attributing al uppermantie VLVA, or regions of extensive volcanism, to plume heads. The Indian ocean was insulated by Pangaea, was isolated from subductjve cooling, has been swept by migrating ridges and triple junctions which undoubtedly initiated upwelling and melting, and is underlain by hot lower mantle. The $150 \mathrm{Ma}$ pre-heating time between plume head injection and magmatic activity, as proposed by Kent (1991), should have done significant damage to the S Gondwana continental lithosphere. As we discuss later, there is little evidence for such damage.

\section{A modest proposal}

The mantle is certainly convecting and there are therefore hot buoyant upwelling regions and cold, dense descending regions. What role this convection plays in driving the plates or (vice versa) and controlling their spced and direction is uncertain. In the Morgan (1971) plume theory hot upwelling plumes play a dominant role. Most current investigators assign a dominant role to the plates (Forsyth \& Uyeda 1975; Hager 1978); body forces on the thickening plate and sinking blabs control plate velocities and directions, and perhaps, the planform of uppermantle convection. Plate divergencies and convergerices probably control, to a large extent, convection cell boundaries in the mantle.

Lateral temperature gradients can also drive convection, and in this case, there is no critical Rayleigh number. Currents flow from hot toward cold areas. Froidevaux \& Nataf (1981) discuss this mechanism using cold vertical slabs as the source of cold and obtain upwellings near the centres of large continents. Cold slabs at the basc of the system can also set up lateral temperature gradients, Officer \& Drake (1983) con. clude that lateral density gradients beneath the plates are important in driving mantle convection. Upwellings associated with these mechan- 
isms may bo confused with deep mantic thermal boundary layer instabilitics, or plumes. Partial melt zones in the uppermantle can also generate upwellings unrelated to TBL.

The tomography shows that the mesosphere under Africa, Antarctica and the Indian ocean has low seismic velocities and these regions are therefore probably hot. A long wavelength geoid high is centred over Africa and it has been proposed that this region has been lot for several hundred million years (Anderson 1982b). The $S$ Indian ocean region may bave been as well (Kent 1991). The central Pacific, is also a long wavelength geoid high and has low uppermantle seismic velocities. The large plateaus in the W Pacific (Ontong Java, Shatsky Rise, etc.) may have formed over the S Pacific, suggesting hot mantle, or hotcells, has existed there since at least the early Cretaccous (Anderson 1989). This region has not experienced slab cooling for a comparable period of time and has been a region of constantly changing ridge and triple junction configurations. We suggest that since the break-up of Pangaea the circum-African continents have been moving from hot mantle toward cold mantle, driven both by the uppermantlemesospheric lateral temperature gradients and slab-plate body forces. If so, most of the continents have reached the end of their journcy since, to proceed further, they must intrude into hot Pacific mantle. North America, in particular, seems to be boxed in by hot mantle. Continents and their associated subduction zones also appear to have been moving toward cold, downwelling lower mantle.

The continents moving toward continentdipping trenches and, therefore, overriding cold oceanic lithosphere, will insert cold slab into the mantle beneath them and in their trail, until they get close to a ridge. Thus, the high-velocity regions under parts of the Atlantic and Indian oceans probably reflect mainly subduction cooling but they may also have been relatively cold prior to the break-up of Pangaea.

On the other hand the high velocity regions in the mesosphere under northern Europe and central Asia, the Arctic and parts of the Pacific have not experienced recent subduction and these may be the regions toward which uppermantle flow was directed during the initial breakup of Pangaes, at least that component controlled by lateral temperature gradients. These cold regions may reflect slabs subducted during the assembly of Eurasia.

If this analysis of the present tomography is taken as a guide we predict deep uppermantle currents directed north from Antarctica and the southern oceans and from the Pacific toward
Eurasita and the Arctic and from Africa toward the surrounding areas. Smaller scale diverging flows in the transition region may originate under the north Atlantic, western Australia, and the Indian geoid and velocity low. Horizontal temperature gradients can drive mantie fiow and continental drift (Elder 1967; Oificer \& Drake 1983). The mantle currents discussed above may also represent the 'return flow' which balances the plate motions. The very low seismic velocities and, presumably low viscosity, under the Indian-Australian plate may explain why this plate is moving rapidly in spite of having several continents and little slab. Superposed on the thermal cnrrents in the sublithospheric mantle are plate induced motions, generally directed from ridges to trenches.

The scale of mantle convection is unknown. The scales of swells and uplifted regions have secently been taken as the scale size of plume heads. However, they could instead be telling us the size of uppermantle convection cells. There are probably many hotcells under the Pacific plate, perhaps elongated in the spreading direction by plate drag (Maia \& Diament 1991). It is of interest that the most active current hotspot, Hawaii, is downstream from the most rapidly spreading segment of the EPR. There is no obvious plume bead associated with the Hawaiian hotspot, in the sense that CFB provinces are altributed to the Tristan, Réunion, Heard and Iceland hotspots. Tomography shows that there are vast LVA in the uppermantle and that ridges, hotspots and CFB initiation sites tend to occur in these regions. These regions have also not been cooled by subduction. Uppermantle convection cells will be embedded in these VLVA and some may be hotter, or convecting more vigorously, than others. Convection may even be intermittent, causing periodic overturn. What we call 'hotspots' may be related to these types of phenomena, plus lithospheric extension, tather than to narrow deep plume tails extending to the core. Nevertheless, plume tails and heads, and whole mantle convection schemes have become popular and we will next test these with the tomographic results.

\section{Plume heads, continental lithosphere and flood basalts}

Recent models for continentai flood basalts include (1) the initial impact of a giant mushroom phume head (the 'starting plume' hypothesis; Richards et al. 1989; Hill et al. 1991) (2) melting caused by lithospheric thinning over a steadystate plume (White \& McKenzie 1989) or (3) 
delamination, melting or remobilization of the continental lithosphere (CL; Hawkesworth et al. 1986). In contrast to these plume-telated hypotheses there is the possibility that plate reorganizations, extensional stresscs, zones of weakness in the lithosphere and the prior existence of hot or partially molten regions of the mantle (hotcells) are involved in massive basaltic outpourings. There may be extensive hot regions of the uppermantle that are unrelated to the recent arrival of a plume head, and which can provide massive amounts of basalt if the overlying lithosphere is put into tension.

High-resolution surface waye tomography can be used to test the plume head and lithospheric damage (thinaing, stretching, remobilization, heating or delamination) hypotheses. We find no evidence, at our resolution, for the involve. ment of plume heads or lithospheric modification at any of the sites of Triassic to Tertiary continental flood basalts. These massive outpourings of basalt seem rather to be related to plate tectonic reorganization, over broad deep regions of hot, probably partially molten, mantle. Pieces of thick continental lithosphere apparently can separate along lines of weakness, such as suture zones, without substantial rifting or thinning, allowing egress to already buoyant, or even partially molten, mantle, which melts further upon ascent and decompression. Cratonic lithosphero probably formod at high temperature and appears to be immune to significant thermal damage with current mantle temperatures, both because it is cold and because it is refractory.

\section{Plume theories}

In the plume theories the mantle is assumed to be nearly isothermal except in the vicinity of a plume. In multicell convection, with variable surface (lithosphere) conditions and high-viscosity slabs there can be large lateral temperature gradients (Anderson 1982b; Froideyaux \& Nataf 1981; Gurnis 1988). The tomography shows this as well. In each convection cell, of course, there will be an upwelling or 'plume' but all convection cells are not the same temperature. The 'cold' downwellings of hotcells may be hotter than the 'hot' upwelling parts of coldcells. The point is that in a realistic mantle there are lateral temperature gradients (and variations in volatile content). Individual cells may be relatively isothermai, homogeneous and well-mixed. Plume theories are based on numerical, laboratory or conceptual experiments that involve uniform boundary conditions and, at most, a few cells. Generally, the system is heated from below and has consiant properties and no phase changes. Such a world has a few hot plumes to remove the heat from the bottom of the system to the top; plumes arise from instabilities in the lower thermal boundary layer. All convection cells are about the same. For a real mantle, there is non-uniform heating from below (for uppermantle convection), non-uniform cooling from above, internal heating, moving plates and induced upwelling from above. Therefore, regions that arc hotter than average, or even partially molten, are not necessarily plumes. Continental flood basalt (CFB) volcanism is characterized by rapid eruption of large volumes of basalt, typically $10^{6} \mathrm{~km}^{3}$ in $10^{6}$ years. Often, CFB are associated with rifting and continental breakup although sometimes the magmatism precedes extensive rifting. Richards et al. (1989) argue that major CFB provinces are consequences of the initial arrival of deep-seated mantle plumes which promote continental breakup. White \& McKenzie (1989) argue for an anomalously hot, usthenospheric mautle, associated with steadystate plumes, in order to generate large volumes of basaltic magma at relatively shallow levels. Lithospheric stretching and thinning is required to allow ascent and melting of the anomalous asthenospherc, i.e. the asthenosphere is normally sub-solidus.

The ascent and melting of the large head of a new plume has been suggested as the cause of the anomalously large rate of eruption of modern flood basalts over short periods of time near the beginning of many hotspot tracks (Morgan 1981; Courtillot et al. 1986; Richards et al. 1989; Hill et al. 1991). Griffiths \& Campbell (1990) argue that flood basalts are the result of large spherical masses from the core-mantle boundary which collapse to $2000 \mathrm{~km}$ diameter pancakes when they encounter the lithosphere. The plume head consists of hot core-mantle boundary (CMB) material and, mostly, entrained material from the lowermost mantle above $D^{\prime \prime}$ (the fayer at the base of the mantle). As the giant sphere enters the uppermantle it no longer entrains ambient mantle but simply pushes it aside. Magmatism resulting from plume heads is therefore a combination of lowermost and lower mantle material but no uppermantle or asthenospheric material. Plumes are assumed to consist of a large, composite buoyant spherical vortex head followed by a narrow, hot, uncontaminated tail containing material from just above the molten iron core. One would expect the highest temperature mantle maguas (picrites, komatiites) to be representative of plume tails and the enriched source region in the plume head-tail theories, and to be depleted in Ander- 
son's $(1981,1982 d, 1983 a)$ depleted mesosphere theory. In Anderson's model the meosphere was depleted by the removal of a small melt fraction to the continental crust and the shallow mantle (perisphere). It is maintained as a depleted reservoir by de-metasomatization, at shallow depth, of the downgoing slab. A metasomatized shallow mantle is consistent with mass balance calculations (Anderson 1983a).

White \& McKenzie's (1989) explanation for flood basalts is quite different than Griffiths \& Campbell (1990). This involves externally imposed lithospheric extension coincident with a hot steady plume. In thicir model a steady flow ascends and cools by conduction as it sprcads laterally below the lithosphere, It melis and causes hotspots only if the overlying lithosphere is coincidently stretching and thinning. The asthenosphere is depleted, as it is in most theories, and fuels the midocean ridges. Griffiths \& Campbell (1990) criticize the steady plume hypothesis because they do not believe it explains $\mathrm{CFB}$ coincidenoe with the initiation of hotspot tracks, the absence of volcanism prior to the CFB and the very short duration of anomalous rates of eruption. On the other hand, Griffiths \& Campbefl (1990) ignore exiernally imposed, or platc tectonic, extension and rifting, the role of melting, the interaction of plumes with mantle convection and plates, the spacing of plumes, their initiation in a convecting, internally beated mantle and the expected geochemistry of source material in contact with the core. Neither theory addresses the source of MORB after the near-ridge asthenosphere is filled with plume heads.

White \& McKenze (1989) do not address the depth of origin of plumes nor how they form. However, their hypothesis and the original plume hypothesis of Morgan (1971) view plumes as the main sources of mantle upwelling, which are therefore simply the rising parts of mantle convection cells albeit, very narrow. In the plume head hypotheses, plumes are viewed as small-scale thermals superimposed on the main scale of mantle convection. In the uppermantle version of the starting plume hypothesis plume heads, which originate in the uppermantle, are much smaller and little entrainment occur, i.e. they consist almost entirely of source material, which would be the subasthenospheric transition region, or mesosphere (Griffiths \& Campbell 1990). In this model, uppermantle plume heads, upon spreading, cannot achieve the latcral dimensions observed for flood volcancism supporting the hypothesis that plumes responsible for flood basalts originate at the core-mantle boundary' (Griffiths \& Campbell 1990).
The lithosphere and asthenosphere are not involved in the melts that constitnte CFB in the starting plume hypothesis. The melts are entirely from a mechanical mixture of CMB material and entrained lowermost mantle. In the White-McKenzic version of the plume hypothesis, plumes consist mainly of uppermantle material which partially melts to provide CFB when the lithosphere thins adequately. In the lithospheric delamination or remobilization schemes CFB are derived from the continental lithosphere. The asthenosphere is generally thought to be depleted and the source of midocean ridge basalts. Piume material is almost invariably thought to arise from an enriched or primitive reservoir, either shallow (CL) or deep mantle. Depleted MORB-like picrites and komatiites, the best candidates for plume material, are paradoxes in these schemes. Lithospheric remobilization is attributed to continental collision, or stretching, or the impact of a plume of unspecified composition. If the hot, bouyant upwellings are depleted then they may pick up their enriched geochemical signature in the metasomatized shallow mantle (Anderson $1983 b, 1985)$.

In the White-McKenzic theory, lithospheric heating and thinning is an intrinsic part of the CFB story. Extensive melting only occurs when the lithosphere becomes acceptably thin. The continental lithosphere originally adjacent to hotspots and overfying the plume heads should differ from the lithosphere elsewhere along the break which may develop into a new ocean. In addition, the plume head is entrained by the plate and dragged along by the diverging lithospheres.

Many authors would like to erode, delaminate or remobilize the continental lithosphere by plume heads or processes associated with continental collision or breakup (Hawkesworth et al. 1986; Storey et al. 1989; Mahoney et al. 1989, 1991). Specifically, lithospheric removal has been proposed for Brazil, India and Madagascar and implied for other CFB sites. Delaminated continental lithosphere has been proposed as a general source of enriched basalts by Allegre \& Turcotte (1985) and McKenzie \& O'Nions (1983). In all cases the motivation was to insert enriched material into the 'asthenosphere' or 'convecting mantle' which, it is widely felt, would otherwise be depleted and unable to provide CFB or ocean island basalts (OIB). The alternative is that there is a global shallow, inhomogencous enriched or metasomatized layer (refractory peridotite) which overlies the depleted reservoir (Anderson 1983b, 1989) and which contaminates or mixes with basalts from 
the deeper more fertile reservoir. Hot regions of the mesosphere provide the bulk of the material (basalts) to spreading ridges, hotspots and continental flood basalt provinces and these basalts are variably contaminated by the easy melting components of the shallow mantle, which is melted by adiabatically decompressing and melting plume or diapir material. Continental tholelites are often attributed to asthenospheric upwelling and melting of enriched heterogeneous subcontinental lithospheric mantle. A1though this process is unlikely because of the low temperature and probable infertility of the continental lithosphere (as opposed to the shallow mantle under the lithosphere) the predictions for seismic tomography would be similar to the plume head and lithospheric delamination or reactivation scenarios. In the Anderson (1989) scenario, the shallow mantle (perisphere) is enriched but not necessarily fertile and this contaminates depleted basalts from slightly greater depth. The shallow mantle can be contaminated (enriched) by subduction (dehydration, sediments) and by trapped, small volume melts (kimberlites, lamproites). When plumes reach the surface they are mixtures and can range from depleted to enriched. This is similar to the continental lithosphere contamination models but the enriched layer is viewed as global and thick and weak, or low viscosity, rather than lithospheric. It is isolated from the rest of the mantle by its buoyancy and low viscosity. We call this layer the 'perisphere'. Chemically, it plays the role that many attribute to the continental ifthosphere but physically it behaves as asthenosphere. The perisphere is constantly refreshed by recycling, slab dehydration and residual $L I L$ rich melts. It is constantly being depleted by eruption of enriched magmas.

A minority opinion holds that within-plate magmatism is the result of lithospheric dynamics and plate reorganizations rather than rising deep mantle plumes (Giret \& Lameyre 1985; Phipps 1988; Zchnder et al. 1990; Sykes 1978). In the deep mantle plume hypotheses hotspots appear at random times and places since the source layer is remote and decoupled from plate tectonics and the locations of extending lithosphere, continental boundaries, lithospheric discontinutities and zones of weakness. The association (i) in space, of hotspot initiation sites with zones of crustal weakness, lithospheric discontinuities, cratons and ridges, and (ii) in time, with episodes of rapid plate motion and of plate reorganization are coincidental in the hydrodynamic thermal boundary layer instability models. These models also do not address the relative fixity of hotspots. The thermal boundary layer at the base of the mantle is expected to be as mobile as the surface boundary laycr, and more mobile than a mesospheric boundary layer since the core is essentially invicid. In layered convection models (Anderson 1979a, 1991) the high viscosity of the lower mantle and the very high viscosity of bottomed out slabs can establish a fixed reference system at the bottom of the uppermantle. In uppermantle convection schemes one can view the individual convection cells as relatively fixed to one another and the hot upwelling parts are therefore relatively fixed; they may be the main upwellings rather than scoondary thermals. Convection cells in the uppermantle may have dimensions of $500-1000 \mathrm{~km}$ and clustors of hotcells may remain hot for long periods of time.

The complete plume hypothesis is untestable. The aarrow plume tails, $10-200 \mathrm{~km}$ in diameter, and extending deep into the mantle are below the resolution of geophysical techniques and cannot be resolved by numerical or theoretical computation. They give no signal and have no measurable effect. The geophysical effects (bathymetry, geoid, tomography) of the large flattened plume heads are little different from alternative models of uppermantle structure involving large hot regions associated with larger scales of mantle convection, uppermantle convection cells, continental insulation, absence of subduction, or passive upwellings associated with migrating ridges, or lithospheric discontinuities and other plate induced phenomena. Large seale hot regions in the uppermantle can be generated by a variety of mechanisms. Passively induced upwellings, such as by ridge spreading, sample both the shallow mantle and, as time goes on, or spreading rate increases, the deeper mantle. This is not the place to discuss whole-mantle v. layered-mantle convection but phase changes, viscosity jumps and changes in chemistry can all serve to isolate the uppermantle from the lower mantle.

Recent plume models envisage $1000-2000 \mathrm{~km}$ diameter circular pancake slaped features of order $100-200 \mathrm{~km}$ thick underncath the lithospherc. These hot circular regions either surround current hotspots (White \& McKenzie 1989) or are split and carried along by the lithosphere underneath flood basalt provinces (Phipps 1988; Hill et al. 1991).

\section{Tomography}

Although no geophysical or computational technique can resolve the narrow plume tails conjectured to link plume heads with the deep mantle there are other predictions of the above theories 
that can be tested with available tomographic resolution. We present and interpret a series of tomographic maps; in particular, we look in detail at a number of $C F B$ provinces.

Figure 6 shows the shear-velocity at $230 \mathrm{~km}$ depth. In the plume models we expect to see large low velocity circles surrounding all hotspots, or their conjectured initiation sites (CFB), or elliptical patches elongated in the plate direction. We expect to see shallow linear bands of low-velocity naterial under ridges, updrafts caused by spreading. However, we see broad areas of both low and high seismic velocity. Very low scismic velocitics faithfully follow ridges in the upper $100 \mathrm{~km}$ (Fig. 4), By $300 \mathrm{~km}$ depth, however, the band of low-velocities in the Atlantic extends from the Azores along the north central MAR and then to Cape Verde, Asconsion, St Helena, and Tristan (the reader unfamiliar with hotspot names should consult a globe or an atlas). This brings up the question of whether the hotspots which are embedded in this 'fossil ridge' feature are active or passive, Certainly the hotspots which are outside this feature (Jan Mayen, Great Meteor, Fernando, Arnold, and Trinidade) are relatively small and not particularly active. It should be pointed out that some of the slowest regions at depths greater than $200 \mathrm{~km}$ are not associated with hotspots at all. They occur along some continental edges and near some subduction zones.

If the 'midplate' mantle is isothermal, with all intermediate wavelength bathymetry and geoid anomalies caused by lithospheric thickening, exccpt around hotspots (White \& McKenzie 1989; Davies 1988, 1990) then seismic velocities beneath the lithosphere will be characterized by about 40 circular or elliptical patches, $2000 \mathrm{~km}$ in dimension. Figures 5 and 6 show that this is not the situation; there are extensive hot regions in the Pacific and Indian oceans with smaller hot patches and bands elsewhere. There appears to be buoyant sublithospheric support under old oceanic plate.

\section{North Atlantic Tertiary Province, NATP (60 Ma)}

We now discuss the continental flood basalt (CFB) provinoes and their relation to conjectured plume heads. The $60 \mathrm{Ma}$ old basalts of $\mathrm{E}$ Greenland and NW Europe are attributed to the arrival of a plume head (Richards et al. 1989) or extensive stretching of the Greenland-NW Norway-Scotland lithosphere (White \& McKenzie 1989). The conjectured plume tail is now under Iceland and the plume head effects should undedie Greenland, Norway, and Scotland, i.e. damaged lithosphere or entrained plume head. There has been little time $(60 \mathrm{Ma})$ since this cvent for the plume head to cool or for the damaged lithosphere to repair itsclf so the plume head initiation event, or the lithospheric thinning event in the passive plume model, should be readily apparcnt as thin and warm lithosphere, and shallow and hot asthenosphere, Figures 5 and 6 show the seismic velocities at 130 and 230 $\mathrm{km}$ depth and we see that in the lands surrounding Iceland, where the conjectured plume head impacted the North Atlantic, the seismic velocitics are all higher than average, indicating cold mantie. The slow velocities arc confined to the young oceanio regions which did not exist at the time of the conjectured plume head or lithospheric thinning event. The tomography shows a LVA below $400 \mathrm{~km}$ depth north of Jan Mayen, extending from NE Greenland to Spitzbergen. This appears to have fed Iceland, and the northernmost MAR and may have provided basalt to the NATP and, possibly, to Siberia in the Triassic. The VLVA in the N Atlantic could be due to a hotcell, or cells, or a plume head. It is about the size of Greenland.

\section{Deccan traps (65 Ma)}

The Deccan traps formed at $65 \mathrm{Mr}$, presumably over the Reunion hotspot. The responsible piume head would underlie most of W and S India. Storey et al. (1989) proposed that the Indian subcontinental lithosphere slid off and contaminated the Indian ocean asthenosphere during this event. Mahoney et al. (1989) argued that the distinctive character of Indian ocean basalts was the result of continental lithospheric remobilization preceding the break-up of Gondwana, particularly from the portion that would become greater India. We therefore expect to see a large area of thin lithosphere and very slow seismic velocities under most of India. The tomography, however, show fast velocities under the Indian subcontinent and indicates thick and cold lithosphere, and cold asthenosphere (say 110-200 $\mathrm{km}$ depth), The seismic velocities in the Indian lithosphere may be sligbtly lower than for other cratons but it is also a small craton. Heat flow and texural studies (Gupta \& Gaur 1984) are consistent with a thick, cold lithosphere today and during emplacement of the Deccan traps. The Rajmahal basalts in the NE corner of the subcontinent, a possible result of magmatism from the Kerguelen hotspot, also are associated with fast velocities in the shallow mantle. There is therefore little evidence for hot plume heads or thinned lithosphere under these two continental flood-basalt provinces, which should both 
have traumatized the uppermantle under most of greater India. One might entcrtain instead the opposite hypothesis; splitting of cratonic lithosphere (rather than thinning) may allow adiabatic ascent from great depth $(>150 \mathrm{~km})$ and, therefore, extensive melting. The Indian ocean ridge, which was near India at the time of the Deccan magmatism, will abso have induced upwelling,

Gupta \& Gaux (1984) showed that low heat flow is associated with the Deccan trap terrane. There is no sigo of transient thermal perturbations. These are signs of thick lithosphere and a deep CFB source and one that did not significantly perturb the lithosphere. The thickness of the thermal lithosphere just south of the Deccans traps is $200 \mathrm{~km}$ and this region has a normal cratonic beat flow, $37.7 \mathrm{~mW} \mathrm{~m}^{-2}$, similar to that in Siberia. The thickness of the thermal lithosphere, or thermal boundary lnyer, is generally twice that of the elastic lithosphere. The present elastic thickness of the Archaean Slave craton is $100 \mathrm{~km}$, about the same as inforred for the Deccan lithosphere (Grolzinger \& Royden 1990).

Curiously, despite being erupted onto Archaean Craton, only a very small fraction of the Deccan magmas reflect much contribution from material thought to comprise the $\mathrm{CL}$. It was therefore suggested that there was not much ithosphere left under India by the time of the Deccan activity, owing to prolonged convection thinning preceding and during the breakup of Gondwana (Mahoney et al. 1989). These gyrations, regarding the fate of the Indian lithosphere are entirely the result of the perception that CFB should arise from enriched $C L$ and that all basalts from shallow mantle and spreading ridges should be depleted, unless they have been contaminated by $\mathrm{CL}$ or plume material. The alternative is that plumes are initially depleted, or that migrating or slow spreading ridges can tap shallow enriched mantle (the perisphere). It is therefore of interest that India was near a spreading ridge at the time of the Deccan traps. The traps, in turn, are near a major ancient lithosphere break that crosses the subcontinent. The Indian ocean mantle appears to be hotter than average and spreading, of course, induced upwelling and further melting. Thus, it appears that lithospheric conditions (but not chemistry) are involved in CFB and the initiation of hotspots. We suggest that the shallow enriched perisphere can be isolated from the underlying depleted mantle becausc of its intrinsic buoyancy and low viscosity. It has low viseosity because of high-temperature and probably, high volatile content. This layer is, in part, the lower part of the thermal boundary layer. The TBL, in turn, is White's (1988) 'lithosphere'.

\section{Paraná fluod basalts (130 Ma)}

The extensive Paraná basalts in Brazil (130 Ma) and the smaller Etendeka hasalt province in W Africa have been attributed to the arrival of a massive plume head under the South Atlantic, or to a period of preheating and lithospheric extension by a plume head prior to opening of a new ocean. In addition, several authors have suggested that the Brazilian lithosphere delaminated, or slid-off, to contaminate the Atlantic with enriched materials. Hawkesworth el al. (1986) proposed that large portions of ancient Brazilian lithosphere contaminated a belt of South Allantic asthenosphere which is now erupting at hotspot islands (Tristan da Cunha and Gough) which, in turn, contaminate nearby sections of the Mid-Atlantic Ridge. Bonatti (1990) proposed that part of the CL of equatorial South America slid off and remained behind to form the St Peter-Paul islets.

These suggestions were made because of the widespread occurrence of enriched basalts and peridotites in the South Atlantic. If the oceanic uppermantie is depleted, as assumed by most authors, then enriched material must be imported from great distance or great depth. The alternative is the shallow mantic, almost everywhere, is metasomatized or enriched (i.e. in LREE, LIL, ${ }^{87} \mathrm{Sr}^{886} \mathrm{Sr}$ ) even if infertile. In Anderson's (1981, 1983a, b) model the shallow mantle everywhere is enriched, unless shoved aside by long sustained spreading or deep upwelling. This is the perisphere.

Taken together the plume head and $\mathrm{Cl}$. scenarios fill up the entire Indian and South Atlantic oceanic mantle with plume heads and enriched continental lithosphere, leaving little room for the 'undepleted asthenosphere' which is supposed to exist in the shallow mantle everywhere to provide fuel for the mid-oceanic ridge system. The depleted MORB reservoir must therefore be below the enriched layer as in the perisphere model. Figures 5 and 6 show no evidence for the low seismic velocities which should underlie much of Brazil and SW Africa if the plume head hypothesis is valid. Instead we find faster than average seismic velocities in these regions, with the slower velocities confined to the young ocean and the younger parts of Walvis Ridge and the Rio Grande Rise, i.e. the newer rather than the older manifestations of the Tristan de Cunha hotspot. Southern African lithosphere should also have been affected by the earlier Karoo and Madagascar events, in 
cither the plusuc head or lithospheric stretching models of CFB.

The time since the conjectured plume head, or stretching event, about $130 \mathrm{Ma}$, is too short for the lower lithosphere or asthenosphere to cool off substantially, since the major part of the effect is much deeper than the thermal diffusion distance. The regions of South America and Africe which should have been affected by the plume head do not differ from the surrounding contincntal areas. The seismic evidence is therefore not favourable to the plume head, lithospheric stretching or lithosphere delamination hypotheses. It is, however, consistent with Pangaca starting to break-up after having moved over mantle which is hotter in some places than in others. The last places of break-up coincide both with present hotspots and ancient cratons. The Atlantic ocean did not open initially at Tris$\tan$ da Cunha, St Helona and Iceland. CFB and OPB may be the result of rapid draining of an already partially molten shallow mantle, aided by passively induced upwelling from great depth and adjabatic decompression and mclting.

\section{The Karoo (180 Ma) and Siberian (250 Ma) events}

Thesc are two of the more massive continental flood basalt provinces and they have both been attributed to the arrival of a gigantic plume head, or extensive stretching of the lithosphere over a plume head (White \& McKenzie 1989). These CFB provinces are old enough so that some cooling of the affected lithosphere, and top of the asthenosphere, may have occurred but they should still differ from adjacent areas that did not experience these thermomechanical traumas. Figures 5 and 6 show, however, that these regions are no different from other areas in their vicinity. If they were uniformly faster one might argue that the depletion of the plume head in melt offsets the higher temperatures but there is little to distinguish these arcas, which were expected to be damaged by stretching and plume head insertion, from other areas which were not. It has also been proposed that the Madagascar lithosphere was removed during late Cretaceous magmatism by the Marion plume (Mahoney et al. 1991). The lithosphere in this part of the world therefore received double damage in the plume head hypotheses. Actually, southern Africa received triple damage because the later Paraná-Etendeka event also would have affected this area if it were due to a $2000 \mathrm{~km}$ wide plume head.
The inferred lack of damage to the Siberian lithosphere is consistent with an analysis of lithospheric thickness associated with the Siberian trap event. The Siberian lithosphere is calculated to have been $180 \mathrm{~km}$ thick, as measured by deformation acoompanying the loading (Zorin \& Vladimirov 1989). There are several other studies showing normal or thick lithosphere under the sites of continental flood basalt magmatism (Watts \& Cox 1989). The thickness of the Siberian plattorm lithosphere in the late Permian and Triassic, when intensive trap magmatism occurred, differed insignificantly from the present thickncss, 180-200 km (Zorin \& Vladimirov 1989). The heat flow $30-40 \mathrm{~mW} \mathrm{~m}^{-2}$ is close to the minimum values for continents. Normal lithosphere and a sub-lithosphere source for the CFB are indicated.

The Siberian flood basalts formed during a period of rapid continental drift during the final assembly of Pangaca and just after Siberia docked. It was preceded by Ural-Taimyr subduction and back-are extension in Siberia. Pangaea had just drifted rapidly north by $30^{\circ}$, possibly placing Siberia over the North Atlantic Greenland tomographic slow region in the uppermantle, Other events of note at this time include plutons in the Karn massif and USA, massive accretion of terranes in the circumPacific including Wrangellia, Sonoma and Hercynian orogenies, Oslo Graben activation, rifts around Greenland, flood basalts in Morocco, Greece, Iran and the Caucases, an increase in seawater ${ }^{87} \mathrm{Sr}{ }^{\beta 6} \mathrm{Sr}$, and rapid true polar wander. This may have been a time of significant global plate reorganization, and, therefore, extensive magmatism at new plate boundaries.

The rapid continental drift and the massive plate reorganization and mictoplate assembly taking place at the time of the Siberian flood basalts suggests that back-arc basin activity or drift over hot mantle, combined with plate extension, rather than a plume head, may have been responsible for the Siberian CFB. The tomography shows that the polar North AtlanticGreenland area has slow seismic velocities below $400 \mathrm{~km}$ depth. This polar high temperature region is the likely location of Sibcria, just after a rapid northward movement of Pangaea. The North Allantic Tertiary Province occupied approximately this same region $175 \mathrm{Ma}$ later. A large region of the mantle that remains thermally distinctive for a long period of time may represent an uppermantle convection cell or seyeral adjacent cells. The area now represented by the N Atlantic was covered for a long period of time by thick cratonic lithosphere and has not recently been cooled by subduction. 


\section{Discussion}

What are we to make of these tomographic re. sults which seem to contradict the premises of all currently popular plume and flood basalt scenarios? Certainly, there were massive basalt flood events in all the areas discussed. Yet there is no evidence of lithosphere damage or the presence of a massive plume head which has been conjectured to be dragged away from the scene by subsequent plate motions. The hotspots associated with all of these events (except possibly for Siberia which has left no track) are embedded in slower than average mantle and these presumably hot regions can be traced down to 200 to $300 \mathrm{~km}$. At these depths, howcver, the hotspots are not spots but are simply part of an extensive meandering low-velocity region of the uppermantle. These LVA are often parallel to ridges and coastlines rather than to spreading directions. There are many regions at depths between 200 and $400 \mathrm{~km}$ where the velocities are even lower than beneath the suriace hotspots; backarc basins, NE Pacific and the Indian ocean, to name a few. Most of the Pacific ocean has low seismic velocities at most depths in the uppermantle.

The rapid onset and short duration of basaltic flooding events suggests to some (Griffiths \& Campbell 1990; Richards et al. 1990; Hill et al. 1991) that this marks the arrival of a plume head. The steady-state plume model has been discounted by these authors because of the presumed time constraints associated with lithospheric stretching and passive upwelling.

However, in all of the curtently popular plume hypotheses, it is assumed that the mantle is isothermal (based on selective bathymetry) except near plume heads and slabs, and that melting only occurs when a hot plume can rise to depths shallower than the ordinary thickness of the lithosphere. It has also been pointed out that $\mathrm{CFB}$ often precedes extensive rifting (White \& McKenzic 1989; Hill et al, 1991) and that stretching and rifting are often unaccompanied by CFB or that rifting often produces small volume alkalies rather than large volume tholeitic floods. We might point out that CFB tholeites are actually similar to mid-ocean ridge tholeiites and can be considered as contaminated, fractionated MORB, or a precursory picrite, instead of being basalts from an independent, fertile reservoir (Anderson 1982d, 1989). Many hotspots (OIB) are very close in trace element and isotopic chemistry to MORB and some are more depleted than the CFB which are thought to be their initial expression, It may be that the differences between MORB and CFB and other 'enriched' magmas have more to do with shallow mantle (perisphere) interactions than with the fertile reservoir, which they all might share. Dapleted picrites and komatiites may be the deep und hot parent magmas that service both ridges and hotspots.

Off-ridge hotspots tend to be the most enriched. In these cases there is more opportunity for sub-lithospheric cooling, fractionation and contamination with the shallow metasomatized mantle, prior to cruption. The ultimate melts are more likely to be evolved, small melt residues, that indicate deeper crystal-melt equilibration than basalts erupted under thin lithosphere spreading centres. Continental extension or rifting, however, allows massive melting upon adiabetic ascent, or even spilling of accumulated magmas. Thus, eruption through thick lithosphere, or from below thick lithosphere, introduces complications other than the temperature of the sub-lithospheric mantle. That is to say, it is not only the temperature of the uppermantle that controls the chemistry, quantity and style of eruption. The thickness of the lithosphere can, in fact, affect the temperature of the uppermantlc.

Anderson \& Bass (1984) showed that temperatures below some $150-200 \mathrm{~km}$ cven under cold cratons are close to the dry solidus and if material below this depth is allowed to rise adiabatically it will melt. In hotter parts of the mantle, or if the mantle contains volatiles, the melting point is probably generally exceeded at sublithospheric depths. In high heat flow and tectonically active regions the seismic velocities are very slow and imply the presence of melt to depths of order $390 \mathrm{~km}$. Very small melt fractions can cause large velocity reductions, If cratonic mantle rifts, or drifts over hotter than ayerage mantle (hotcells), there can be extensive sublithospheric melting without the need for a deep plume to cause melting or to trigger extensive volcanism. If the overlying lithosphere is unider compression there is little likelihood of melt extraction and melts may pond and be available for rapid extrusion, without extensive precursory rifting, if the stress regime turns to tensile or extensional. The sublithospheric mantle may be contaminated by subduction and metasomstism and, therefore, have chemical properties often attributed to CL. A mixing fractionation scheme for converting deep depleted plumes to enriched OIB-type magmas by shallow mantle processes satisfactorily explains the $\mathrm{Sr}-\mathrm{Nd}-\mathrm{Pb}$ isotope systems (Anderson 1983a, $b$, 1985), as well as the trace-element chemistry of hotspots. The small-melt fraction enriched magmas may be kimberlitic or lamproitic and may also contain recycled sediments and hydrous 
fluids. The perisphero/asthenosphere is probably laterally and vertically inhomogeneous.

There is an interesting correlation of hotspot initiation sites and the presence of ancient thick cratonic lithosphere. The cratonic plate is probably about 180-220 km thick (Anderson \& Bass 1984; Anderson 1990). The Archaean cratons are particularly evident in the tomographic maps of Zhang \& Tanimoto $(1991 a, b, 1992)$. Surfaco wave studies may have less radial resolution than body-wave studies and the shallow ligh-velocities may be smeared to greater depth but, in any case, the velocities above $200 \mathrm{~km}$ under the oldest cratons are faster than elscwhere, including other ancient platforms. Precambrian shields, in general, are themselves faster than younger areas, and the high-velocities extend to greater depth. The seismic plus the flexural studies therefore imply thick $(100-200 \mathrm{~km})$, cold, strong lithosphere under ancient cratons. Part of this is due to temperature but there is probably also a mineralogical or chemical component to the high velocities (Anderson \& Bass 1984).

We bave already mentioned that many of the CFB provinces, including those that occurred prior to local sea-floor spreading, are adjacent to thick continental lithosphere or Precambrian shicld crust. These include Paraná, Karoo, Siberia, Greenland and Deccan. Interestingly, the last places to fail as the Atlantic ocean opened up are just those places which have been attributed to the weakening effects of plumes (Morgan 1981). These places are also regions of thick cratonic lithosphere. These age and lithospheric thickness relationships are inconsistent with plume theories and add yet another element of coincidence to the timings and locations of the plumes conjectured to be related to hotspots. The evolution of hot mantle under thick continental lithosphere, and its subsequent adiabatic ascent, are expected to be quite different than under thinner lithosphere. It has often been remarked upon that alkali basalts and CFB tend to occur along ancient suture zones. This is particularly evident for the Deccan traps, which occur near an ancient rift-horst suture that splits the subcontinent of India. The Deccan traps were emplaced on thick cratonic lithospherc, along an ancient suture, near a new Indian ocean spreading centre, on a spuall rapidly moving continent. This is another series of coincidences in the decp mantle plume hypotheses:

\section{Fixity of hotspots}

The relative fixity of hotspots was one of the initial motivations for anchoring them in the deep mantle which, at the time, was thought to be non-convecting and rigid (Wilson \& Burke 1972; Burke \& Wilson 1976). Associating hotspots with propagating fractures, plate reorganizations or lithospheric discontinuitics bas been criticized for not providing a fixed reference system. Contrary to common belief, however, there is no rationale for assuming that deep mantle plumes, particularly from $D^{\prime \prime}$, should be fixed relative to one another or stationary relative to the plates e.g. 'It should also be pointed out that steady deep plumes also do not provide a convincing explanation of stationarity of hotspots since plumes in bigh Rayleigh number convection tend to move horizontaily on times comparable to the turn over time scale of the mantle $\sim 10^{8}$ years' (Griffiths 1986); 'The fixity of hotspots with respect to plate motions is difficult to explain with simple mantle convection models. In fact, no numerical experiment bas ever demonstrated such behaviour, that is, plumes that are independent of upper boundary layer motions' (Duncan \& Richards 1991). When a relative motion between hotspots was inferred by Molnar \& Stock (1987), Olson (1987) asserted that such motion was to be expected for entities arising from such a deep source. Actually, if hotspots are fixed to one another for periods as long as 120 million years, as argued by Duncan \& Richards (1991) then this is evidence for robust phumes, rather than frail plume tails. One should favour the association of strong hotspots with the main buoyant mantle upwellings or particularly hot convection cells. Hotspot fixity also suggests a layered mantle style of convection where high-viscosity bottomed-out slabs, hot regions of the high-viscosity lower mantle, convectively maintained bumps on chemical interfaces, and stagnation points of uppermantle return flow can provide a stable uppermantle reference system. Individual uppermantle convection cells may also maintain their position relative to other cells. 'Hotspots' may actually be hotcells. In multicellular convection distant cells do not communicate readily or rapidly. Because of the shearing action of plates and their ability to entrain shallow uppermantle material one would want to have the hot upwellings to originate at, or to extend to, depths of at least $300 \mathrm{~km}$ and, possibly, into the transition region. These hot regions of the uppermantle probably preferentially occur in areas where subduction has not been extensive for the past $100 \mathrm{Ma}$ or so. It is not necessary, as generally assumed, that upwellings originate in thermal boundary layers since phase changes and partial melting can also trigger instabilities. Rifting and spreading can also initiate upwellings. 
Once an upwelling initiates, it generates buoyancy and low-viscosity and mny maintain itself in one place, just as has been proposed for lower mantle plumes, It beurs emphasizing that there is no chemical ot physical characteristic of hotspots that demands a lower mantle or CMB origin, or even an origin in a thermal boundary layer. We still have no convincing evidence that hotspots are the result of active upwellings or that they are due to lower thermal boundary instabilities. If hotspots are the tops of active upwellings, they could represent hot uppermantic convection celis, in a steady-state scenerio, or an overturning uppermantle convection cell, in an unsteady convection scenerio. They do not need to be the tops of deep mantle thermals.

The location of the enriched, or hotspot, reservoir is not agreed upon. Many authors feel that either a strong contincutal lithosphere or the lower mantle are the only possible locations of ancient isolated reservoirs. What is needed is a mechanism that allows about $1-2 \mathrm{Ga}$ of isolation between the depleted and enriched reseryoirs. The enriched rescrvoir may consist, in part, of ancient recycled continental material so it needn't be completely isolated for this amount of time. Also, the depleted reservoir may have becn even more depleted in the Archaean so it also need not be completely isolated. The best location for an ancient depleted reservoir is bolow the depth of slab dehydration and sediment removal, and the depth of melt trapping by rising diapirs or sublithospheric magma ponding. The mesosphere is one such location. A strong buoyant layer, restricled to continental mantle is unstable (Kincaid 1990). A low-viscosity buoyant (possibly volatile-rich) layer can probably avoid entrainment into the deeper mantle (the oil slick effect) and is a suitable source and sink of enriched material.

Considering the extensive regions that Zhang \& Tanimoto (1991a, b. 1992) have found in the uppermantle having extremely low seismic velocities, and apparently high temperature, we see no reason why lithospheric extension over particularly bot regions cannot lead to extensive basaltic voleanism, whether these extended regions occur in continental or oceanic regions, or whether or not stretching is extensive enough actually to cause melting in unmelted mantle. It is not even necessary that a local upwelling was occurring prior to lithospheric extension.

As a check on this hypothesis we might look for correlations between uppermantle low velocity regions, plate stresses and the presence or absence of extensive magmatism. The association of magmatic provinces with low-velocity re- gions beneath extending plates is fairly obvious. We now ask, what about those lot regions which are amagmatic and what about those regions which have experienced tension without massive volcanism?

There are extensive low-yelocity regions under the Indian ocean, Central America, western equatorial Pacific, and the western Atlantic. These are all arcas of rcgional convergence or compression. They lack midplate volcanism confirming that hot uppermantle is not a sufficient condition for magmatism. On the other hand many areas of Europe and Asia, such as Lake Baikal and the Rhine graben, aro obviously under extension but lack extensive volcanism, presumably because the uppermantle is cold, as judged from the high seismic velocities. Somc of these regions experienced secondary extension associated with convergence, a condition that can cool off the uppermantle if the lithospherc is thick. Rifting in China, back-arc basins, island arcs and high plateaus are examples of secondary extension caused by regional compression.

Extensive volcanism and the existence of nondepleted basalts are often taken as prima facie evidence for the presence of plumes or plume heads. With cqual logic they could be taken as evidence for the existence of lithospheric extension, hot uppermantle and enriched or metasomatized uppermost mantle. The presence of extensive volcanism and depleted basalts could also be taken as evidence for long sustained extension and the tapping of larger and deeper volumes. A moving plate, overriding a hot rogion of the mantle, and being put into tension, will behave, in many respects, as if it were being impacted from below by a giant plume head.

An internal contradiction in the plume head theorics is the displacement of 'depleted asthenosphere' by plume material along the mid-Atlantic and other oceanic ridges. The geochemical rational for importing enriched or non-depleted material from depth, in a plume, is that the shallow mantle (asthenosphere) under midocean ridges is 'known' to be depleted.

A given convection cell may tend loward homogeneity and a relatively limited range of temperalure. However, there are probably many convection cells in the mantle and distant ones do not readily equilibrate with each other, in either chenistry or temperature. Particularly hot cells may even be delivering melt to the base of the lithosphere. Hotcells are an alternative to plume heads. Plume theories presuppose a more-or-less isothernal mantlc and require that anomalously hot mantle be imported from great depth. The tomography shows that the upper- 
mantle is far from isothermal and that VLVA do not appear to be circular plume heads or to be restricted to hotspots.

\section{Perisphere}

Anderson (1987a, 1989) suggested that basalts represent blends of melts from a deep depleted fertilc source and a shallow refractory enriched layer. The shallow layer is enriched by subduction, primarily by dehydration of the upper part of the slab, and trapped small melt fractions such as lamproites or kimberlites. For example, CFB and OIB could be deeply derived depleted tholeiites or picrites which have been contaminated by lamproite melts as they eyolve and cool in the shallow mantle. Because the shallow enriched layer could bc, mechanically, either lithosphere or asthenospherc, we prefer to refer to it as the 'perisphere'. Since mantle has littlo strength at temperatures above $550-650^{\circ} \mathrm{C}$ most of the enriched shallow mantle is formally the asthenosphere. A wcak, low-density shallow tayer can be isolated from the underlying mantle because it is difficult to entrain. On the other hand it may be pushed aside or depleted by the earlicst stages of passive or active upwelling of the deeper mantic. The new word is necessary because the asthenospbere is often referred to as 'depleted' and the continental lithosphere is usually referred to as 'enriched'. The word 'asthenospherc' is also used interchangeably with 'uppermantle', 'convecting mantle' and 'well mixed mantle' as well as 'depleted mantle'. The uppermantle is not necessarily homogeneous or entirely depleted (Anderson 1983a). Hotspot magmas could obtain their distinetive geochemical signatures by small melt fractions from the metasomatized shallow layer, both under continents and oceans. A prediction of this model is that picrites and komatiites, i.c. high temperature or large-volume melts, are depleted in the large-ion lithopbile elements and low in ${ }^{87} \mathrm{Sr} /{ }^{86} \mathrm{Sr}$ and that enriched magmas are replaced by depleted magmas as tontinental rifting evolves to sea-floor spreading. Mature and rapidly spreading ridges should be the most depleted. Migrating ridges should tap more of the shallow mantle and, therefore, be more enriched (e.g. Indian ocean ridges). The small-volume melts from the perisphere (LIL and isotopically enriched) are probably triggered by ascent of deeper, more fertile plumes or diapirs.

We have used 'uppermantle' throughout this paper instead of 'upper mantle'. In the current literature the following equalities are assumed: upper mantle $=$ convecting mantle $=$ depleted mantle $=$ MORB-source $=$ well mixed mantle.
We wish to refer to 'uppermantle' simply as the mantle above the $650 \mathrm{~km}$ discontinuity. It is not necessarily homogeneous, well mixed or unlayered or convecting as a unit. We feel that much unnecessary sematic confusion exists simply because of unproved attributes which have becn assigned to conventional terms such as 'lithosphere', 'asthenosphere' and 'upper mantle'. The 'lower mantle' itself has also been variously described as 'primitive', 'primordial', 'undegassed', 'OIB-source' and so-on. Some geochemical attributes of OIB are automatically assigned to a lower mantle souree because it is 'known' that the upper mantle is homogeneous and depleted. The lower mantle may, in fact, be depleted instead of primitive or enriched, and barren instead of fertile (Anderson 1983a).

We appreciate the advice of aeveral anonymous revjewers and thank B. Storey for his toospitality during the meeting and his patience regarding the manuscript. This work was supported by National Science Foundation Grants BAR-90-02947, BAR-91-08246, BAR-91-03526, and OCE-91-16213. Contribution No. 5117, Division of Geological and Planetary Sciences, California Institute of Technology, Pasadena, CA 91125.

\section{References}

Al.IIGR, C. J. \& Turcotre, D. L. 1985. Geodynamic mixing in the mesosphere boundary layer and the origin of occavic islands. Geophysical Reseanch Letters, 12, 207-210.

Andissos, D. L. 1975. Chemical plumes in the mantle. Geological Society of America Bulletin, 86, $1593-1600$.

- 1979a. Chemical stratification of the mantle. Journal of Geophysical Reseanch, 84, B11, 6297-6298.

- $1979 b$. The upper mantle transition region: Eclogite? Geophysical Research Leifers, 6, 433-436.

1981. Hospots, basalis and the evolution of the mantle. Science, 213, 82-89.

1982a. The chemical composition and evolution of the mantie. In: AkTMOTO, S. \& MAKGHNANI, M. H. (eds) High-Pressure Research in Geophysics. Advances in Earth and Planetary Science, 12, 301-318.

- 1982b. Hotspots, polar wander, Mesozoic convection, and the geoid. Nanure, 297, 5865, 391-393,

- 1982c. Isotopic evolution of the mantle; a model. Earth and Planetary Science Letters, 57, 13-24.

1982d. Isotopic evolution of the mantle; the role of magma mixing. Earth and Planetary Science Lellers, 57, 1-12.

- 1983a. Chemical composition of the mantle. Journal of Geophysical Research, 88, supplement, B41-B52.

$1983 \mathrm{~b}$. Kimberlites and the evolution of the 
mantle. In: Konvraosst, J, (ed, ) Developments int Peirology. Proceedings of the Third Kimberlite Conference Vol. 1, 395-403.

1985. flotspot magmas can form by fractionation and contamination of MORB. Nature, 318, $145-149$.

- 1987a. The Depths of Mintle Reservoirs. In: Mrsen, B. O. (ed.) Magmatic Processes: Physiochemical Principles. Special Publication No. 1 cdition, Geochemical Socicty.

1987b. Global mapping of the uppermantle by surface wave tomography, in composition, structure and dynamics of the lithosphere asthenosphere-system. In: FuCHS, K, \& FroipkVACX, C. (eds) Geodynamics Series. American Geophysical Union, Washington DC, 16, 327.

1989. Theory of the Earth. Blackwell Scientific Publications, Boston, 1-366.

- 1990. Geoplaysics of the continentai mantle: an historical perspective. In: Menzies, M. (ed.) Continental Mantle. Clareudon Press, Oxford.

1991. Chemical boundaries in the mantle. In: SABADINI, R. \& LAMBECK, K. (eds) Glacial Isostacy, Sea-Level and Mantle Rheology. Kluwer Academic Publishers, Dordirecht, 379-401.

_ \& BAss, J. D. 1984. Mineralogy and composition of the upper mantle, Geophysical Rescanch Letters, 11, 637-640.

- E BAss, J. D. 1986. The transition region of the Earth's upper mantle. Nature, 320, 321-328.

—, TAмimoro, T. \& Z.HANe, Y.-S. 1992. Plate tectonics and hotspots: The third dimension, Science, 256, 1645-1651.

BAUDRY, N. \& KROENKE, L. 1991. Ittermediatewavelength (400-600 km) South Patific geojdal underlations: their relationship to linear volcanic chains. Earth Planetary Science Letters, 102, $430-443$.

Bosatri, E. 1990, Subcontinental mantle exposed in the Atlantic-ocean on St-Petor-Paul Islets. Nature, 345, 890-802.

BuRKR, K, C. \& WiLson, J. T. 1976. Hot spots on the Earth's surface. Scientific American, 235, 46-47.

Самғаен, I. H. \& Grifrth, R. W. 1990. Implications of mantle plume structure for the origin of flood basalts. Earth Planetary Sctence Letters, 99, $79-93$.

CAmpaell, P., Grifmits, R. W. \& Hill, R. 1. 1989. Melting in an Archaean mantle plume: Heads its basalts, tails its komatiites. Nature, 339, 697-699.

Cantarer, P. \& Limpolt, H. J. 1977. Alter und Abfolge des Vulkanismus der Hucheifel, Neves Jabrbuch fuer Mineralagie. Geologie und Palaeontolgie Monetsheffe, 600 - 512 .

Cazenave, A. \& LaGo, B. 1991. Long wavelength topography, seafloor subsidence and flattening. Geophysical Research Letlers, 18, 1257-1260.

Cous, P. \& Furirour, L. 1990. Topography of the ocean floor: Thermal evolntion of the tithosphere and interaction of deep mantle heterogeneities with the bithosphere. Geophysical Research Letfers, 17, 1961- 1964.

Courmuor, V., Besse, J, VAndamme, D., MoN:
'ITGNY, R., JAEGLE, J. J. \& CoppeitA, H. 1986. Dccan flood basalts at the Cretaccous/Tertiary boundary? Earth and Planetary Science Leiters; $80,361-374$

Cserreres, L. \& Cimistransen, J. 1990. Three-dimensional convection inder drifting plates. Geophysical Research Letters, 17, 1497-1500.

DAvies, G. F. 1988, Occan bathymetry and mantle convection 2. Small-scale flow. Joumal of Geophysical Research, 93, 10481-10488.

- 1990. Mantle plumes, mantle stirring and hotspot chemistry. Earth and Planctary Science Leiters, 99, 99-109.

DAvir, F. J. 1981. Geophysical studies in the Ross Sea region. Journat of the Royal Society of New Zealaind, 11, 465-479.

Duncan, R. A, \& Richaros, M. A. 1991. Hotspots, mantle pinmes, flood basalts and true polar wander. Review of Geophysics, 29, 31-50.

Dzuewonski, A. M. \& Angerson, D, L. 1984. Seismic tomography of the Earth's interior. American Scientist, 72, 483-494.

ELDER, J. 1967. Convective self-propulsion of continents. Nature, 214, 657-660.

Forsyth, D. \& UYEบA, S. 1975. On the relative importance of the driving forces of plate motion. Geophysical Journal. Royal Astronomical Society, 43, 163-200.

FrotdevauX, C. \& Natur, H.-C. 1981. Continental drift: What driving mechanism? Geologische Rundschau, 166-176.

GARpunkel, Z. 1975. Growth, shrinking and longterm evolution of plates. Journal of Geophysical Reseiarch, s0, 4425-4432.

Gnet, A, \& LAMEYRE, J. 1975. Ituverted alkalinetholeiitic sequences related to lithospheric thickness in the evolution of continental rifts and oceanic islands. Journal of African Earth Science, 3, 261-268.

GRIPPTH, R, W 1986. Dynamics of mantle thermals with constant buoyancy or anomalous internal heating. Earth Plantary Science Letters, 78, $435-446$

\& Campbell, I. H. 1990. Stirring and structure in mantle plumes, Earth Planetary Science Leaters, $99,66-78$.

GROTZINOER, V. \& ROYDEN, L. 1990. Elastic strength of the Slave craton at $1.9 \mathrm{Gyr}$ and implications for the thermal evolution of the continents. Nature, 347, 64-66.

Gurta, M. L. \& GauR; V. K. 1984. Surface heat flow and probable evolution of Deccan volcanism Tectonophysics, 105, 309-318.

Gurvis, M. 1988. Large-scale mantle convection and the aggregation and dispersal of continents. Nature, 332, 695-699.

Hager, B. H. 1978. Oceanic plate motions driven by lithospheric thickening and subdructed slabs. Nature, 276, 156-159.

_ \& Richarps, M. A. 1989. Long-wavelength variations in Earth's geoid. Philasophical Trans. actions of the Royal Society of London, A328, 309-327.

Hawkesivorth, C. J., Mamtovang, M. S. M., 
Taylor, P. N. \& Palacz; Z. 1986. Evidence from the Parana of South Brazil for a contiuental contribution to DUPAL basalts. Nature, 322, 356-359.

HuLt, R. T., CAmpela.L, I. H. \& Grifrtis, R. W. 1991. Plume tectonies and the development of stable continental crust. Exploration Geophysics, 22, 185-188.

Houszman, G. A, 1983. The deep structure of ocean tidges in a convecting mantic. Earth and Planetary Science Letters, 64, 283-294.

JACKSON, E. D. \& SuiN, H. R. 1975. Stross fields in central portions of the Pricific plate. Joumal of Geophysical Research, 80, 1861-1874.

JORDAN, T, H. 1975. 'The continental tectosphere. Reviews of Geophysies and Space Physics, 13, 1-12.

- 1978. Composition and development of the continental tectosphere. Nature, 257, 745-750.

Keodr, S., Anderson, D. L. \& Stevenson, D. J. 1992. Relationship between hotspots and manile structure: Correlation with whole mantle seismic tomography. Proceedings of the NATO-ASI Meeting, Dynamic Modeling and Flow in the Earth and Planets. (In press).

Kent, R. 1991, Lithospheric uplift in erastern Gondwana. Geology, 19, 19-23.

KunCA1D, C. 1990 . The dynamical interaction between tectosphere and large scale mantle convection. EOS, 71, 1626.

Klfin, B. M., Langmuir, C, A, Zindiek, A. Staudigil, H. \& Hamelns, B. 1988. Isotope evidence of a mantle couvective boundary at the Australian-Antanctic discordance. Nature, 333, 623-629.

LAchenghuCI, A. H. 1976. Dynamics of a passive spreading center. Journal of Geopliysical Re. search, 81, 1883-1902.

Lago, B., Cazenave, A. \& Matr.y, J.-C. 1990. Regionai variations in subsidence rate of lithospheric plates. Physics of the Earth and Planetary Interiors, 61, 253-259.

Mahoney, J. J., Natland, J. H, WhIte, W. M., PokmbA, R., BLOOMER, S. M., Fisher, R. L. \& Baxtert, A. N. 1989. Isotopic and geochemical provinces of the western Indian Occan spreadiag centers. Journal of Geophysical Research, 94, $4033-4052$.

_ Nıcortet, C. \& Duruy, C. 1991. Madagascar basolts: tracking oceanic and continental sources. Earth and Planelary Science Letters, 104, $350-363$.

MAIA, M. \& DLAMENT, M. 1991. An analysis of the altimetric geoid in various wavebands in the central Pacific Ocean: Constraints on the origin of intraplate features. Teclonophysics, 190, 133-153.

McKenzie, D. \& O'Nions, R, K. 1983. Mantle reservoirs and occan island basalts. Nature, 301, 229-231.

Molnak, P. \& Stock, J. 1987. Relative motions of hotspots in the Pacific, Atlantic and Indian Oceans since late Cretaceous time. Narure, 327, $587-591$.

Morgan, W. J. 1971. Convective plumes in the lower mantle. Narure, 230, 42-43.
1981. Hotspot tracks and the opening of the Indian and Atlantic Ocernos. In: EmLLIAN!, C. (ed.) The Sea, Wilcy Interselence, New York, vol. 7, 443- 487.

- 1983. Hotspot tracks and the early ritling of the Atluntic. Tectonophysics, 94, 123-139,

Morictenu, C., Cimustenseas, U. \& Fiatout, L. 1991. Geoid and topography associated with sublithospheric convection. Earth and Planetary Science Letters, 103, 395-408.

Natar, H.C., Naxamishi, I. \& Anderson, D. L. 1984. Anisotropy and shear velocity heterogeneities in the upper mantle. Geophysical Research Letters, 11, 109-112.

, _ \& 1986, Measurements of mantle wave velocities and inversion for lateral hetcrogeneity and anisotropy, Part III, Jiversion. Journal of Geophysical Research, 91, B7, 7261-7307.

O'Connor, J. M. \& Duncan, R, A. 1990. Evolutiou of the Walvis Ridge-Rio Grande Rise hot spot system: Implications for African and South American plate motions over plames. Joumal of Geophysical Rescarch, 95, B11, 17,475-17,502.

OrvCER, C. B. \& DrAKE, C. L. 1983. Plate dynamics and isostasy in a dynumic system. Joumal of Geophysics, 54, 1-19.

OxAL, E. \& BAIzı, R. 1987. Hotspots: The first 25 ycars. In: Krinne, B H., Fryen, P.,BAmzA, R. \& Bostulekt, G. W. (eds) Seamotaits, Istanis and Atolls. Geophysical Monograph 43, American Geoplyysical Union, Washington DC, 1-11.

OLsoN, P. 1987. Drifting mantle hotspots. Nature, 327, $559-560$.

Parsons, B. \& Sczatein, J. G. 1977. An analysis of the variation of the ocean floor bathymetry and heat flow with age. Joumal of Geophysical Research, 82, 803-827.

Peate, D. S, Hawkeswoith, C. J., Mantovani, M. \& Shokowsкy, W. 1990. Mantie plumes and flood basalts stratigraphy in the Paraná, South America. Geology, 18, 1223-1226.

PHIPPS, S. P. 1988. Deep rifts as sources for alkaline intraplate magmatism in eastern North America. Nature, 334, 27-31.

Richaros, M. A. \& Wičs, C. W., Jr. 1990 . S-P conversion from the transition zonc beneath Tonga and the nature of the $670 \mathrm{~km}$ discontinuity. Geo. physical Joumal Intermational, 101, 1-35.

- Duncan, R. A. \& Countmlot, V. E. 1989. Flood basalts and hot-spot tracks: Plume hends and tails. Science, 246, 103-107.

Scrnu.r., J.-G, 1973. Tceland mantle plume: geochemical study of Reykjanes Ridge, Nature, 242, $\$ 65-571$.

St EEP, N. H. 1990. Hotspots and mantle plumes: Some phenomenology. Joumal of Geophysical Research, 95, No, BS, 6715-6736.

STOREY, M., SAUNDERS, A. D., TARneY, J., LEAT, P. Thuzlwal, M. J., Thompson, R. N., Menzies, M. A. \& MARriner, G. F. 1988. Geochemical evidence for plume-mantle interactions beneath Kerguclen and Heard islands, Indian Ocean. Nanure, 336, 371-374. 
SYKES, L. R. 1978. Intraplate seismicity, reactivation of preexisting zones of weakness, alkaline magmatism, and other tectonism postdating continental fragmentation. Reviews of Geophysics and Space Physics, 16, 621-688.

TANimoto, T. 1990a. Long wavelength S-wave velocity structure throughout the mantle. Geophysical Journal International, 100, 327-336.

- 1990b. Modeling curved surface wave paths: membrane surface wave synthetics. Geophysical Journal International, 1023, 89-100.

Veevers, J. J. 1984. Phanerozoic earth history of Australia. Clarendon Press, Oxford.

VoGs, P. R. 1991. Bermuda and Appalachian-Labrador rises. Geology, 19, 41-44.

WA' is, A. B. \& Cox, K. G. 1989. The Deccan Traps: an interpretation in terms of progressive lithospheric flexure in response to a migrating load, Earth and Planetary Science Letters, 93, 109-112.

WHrTE, R. S. 1988. The Earth's crust and lithosphere. Journal of Petrology, Special volume, 1-10.

— \& MCKENZIE, D. 1989. Magmatism at rift zones: The generation of volcanic continental margins and food basalts. Journal of Geophysical $R \ell$ search, 94, 7685-7729.

Wilson, J. T, 1990. On the building and classification of mountains. Journal of Geophysical Research,
95, 6611-6628.

- \& BURKE, K. 1972. Plate tectonics and plume mechanics. EOS, 54, 238-239.

ZeHinder, C. M., MUtTer, J. C. \& BuhL, P. 1990. Deep seismic and geochemical constraints on the nature of rift-induced magmatism during breakup of the North-Atlantic. Tectonophysics, 173, 545-565.

Zilang, Y. S. \& TAnimoto, T. 1991a. Global Love wave phase velocity variations and its significance to plate tectonics. Physicy of the Earth and Planetary Interiors, 66, 160-202.

\& TANimoto, T. 1991b. Three-dimensional global upper mantle structure and its tectonic significance. Journal of Geophysical Research, (In press).

— \& TANimoto, T. 1992. Ridges, hotspots and their interaction as observed in seismic velocity maps. Nature, 335, 435-439.

Zhou, H.-W. \& ANDerson, D. L. 1989. Search for Deep Slabs in the Northwest Pacific Mantle. Proceedings of the National Academy of Science, USA, 86, 8602-8608.

Zorin, Y. A. \& Vladimirov, B. M. 1989. On the genesis of trap magmatism of the Siberian platform. Earth and Planctary Letters, 93, 109-112. 